\title{
Christian Outzen på Roost Fogedgård (1732-1809)
}

Cand. jur., husfoged i Haderslev vesteramt og ridefoged i Nørre Rangstrup herred

Af H. P. Jensen

\section{De store Rooster}

Undertiden kan man møde spørgsmålet, om der aldrig har været adel og herregårde i Nørre Rangstrup herred. Svaret er, at det har der næsten ikke.

I 1200- og 1300-tallet var der et tilløb i Roost til fastboende adel, der endda anlagde de store borge Nørrevold (eller Arnsholm) og Søndervold. Det var tilmed meget kendte slægtsnavne, der en tid havde tilknytning til Roost, som slægterne Skram, Munk, Limbek og Sappi. I slutningen af 1300-tallet forsvinder de imidlertid ud af billedet, sandsynligvis en følge af Valdemar Atterdags krige, der også nåede ud til det afsides Vestslesvig. Om de kendte navne er sunket ned til at være lavadel eller almindelige bønder og således fortsat på egnen, kan der kun gisnes om.'

Et voldsted i Bevtoft sogn nævnes i Bevtoft sogns præsteindberetning i 1638 med en forbindelse til adelsslægten Mule. Herom vides dog næsten intet i modsætning til Roost, hvor temmelig mange middelalderlige dokumenter og de store voldsteder giver vidnesbyrd om et adelsvælde.

Men mærkeligt nok stammer flere slægter, der er adlede i nyere tid, fra Nørre Rangstrup herred. Mest kendt er slægten Rostgaard, der tog navn efter den store gård i Roost. Hans Rostgaard indlagde sig megen fortjenste under Svenskekrigen 1658-60, og hans søn Frederik Rostgaard blev adlet i 1702.

Slægten Bertelsen, der ved Troels og Lorentz Bertelsen var herredsfogeder i Nørre Rangstrup herred 1676-1746, blev siden ophav til den adlede slægt Cederfeld de Simonsen med stamhuset Erholm og Søndergaarde. Endelig stammer slægten Oxholm fra Toftlund, hvor en stamfader var degn, og hvor slægten endnu lever ved familien Oxholm i Gøtterup. Det kan også nævnes, at to herredsfogeder, der i kortere perioder beklædte embedet som herredsfoged i Nørre Rangstrup herred, hørte til familier, der af en eller anden mærkelig grund blev adlet så sent som i midten af 1800 tallet. Det var henholdsvis slægterne von Wardenburg og von Stemann, den sidste spillede en ikke ringe rolle helt op i vore dage.

Mange gårde på egnen har haft tilknytning til kendte borge og slægter i 


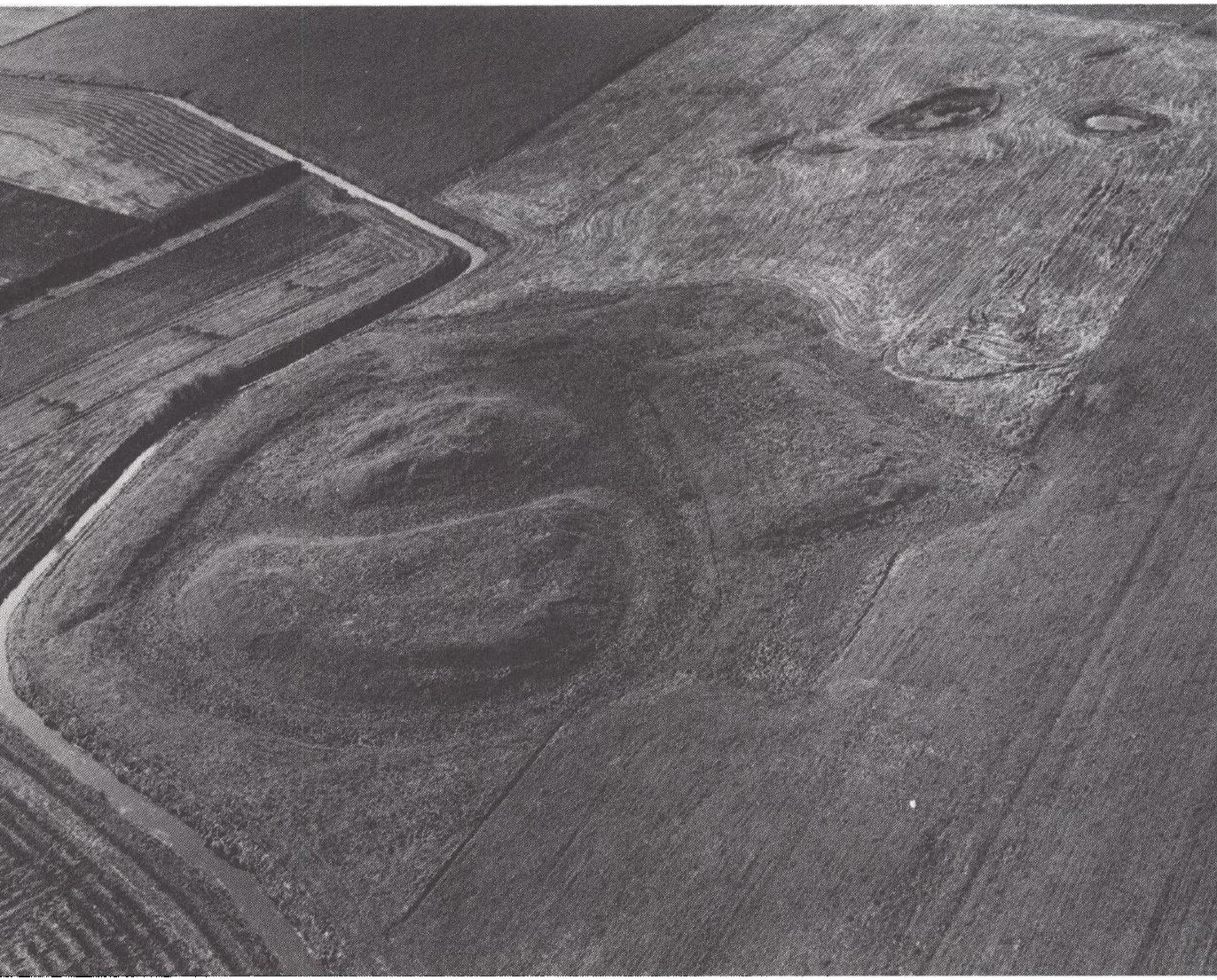

Luftfoto fra 1964 af voldstedet Norrevold eller Arnsholm i Arrild enge, et af Sonderjyllands starste middelalderlige voldsteder, siden 1974 under arkaologisk undersogelse.

Voldstedets bygherre, Valdemar Sappi, ejede 10ottinger jord i Roost og antageligt harder bestået en forbindelse til Roost bys storste gård, den senere Fogedgård.

forgangne tider, men det var som fæstegods under Tørning, Ejsbøl ved Haderslev, Tovskov ved Sommersted eller under grevskabet Schackenborg i Møgeltønder.

Det er imidlertid ikke nødvendigt at have adel for at have en herskende klasse eller blot herskerslægter. Magt beror i reglen på en blanding af penge, god forstand og tilstrækkelig hårdhændethed. Magt vil altid findes og menneskenes børn har det ved sig, at de gerne vil give den videre til deres børn. Det er sådan adel kommer op.

I Nørre Rangstrup herred var Roost den absolut bedste by med god høj kornjord og vældige enge, der gav sommergræsning og vinterhø til sønderjysk 
landbrugs største aktiv: store kreaturbesætninger. I Roost fandtes pengene både som indtægter og formuer. Nogle få slægter holdt styr på det hele og sig selv, og hårdhændetheden forklædtes som embeder med myndighed fra kongen. Ingen slægt illustrerer det bedre end en slægt, der nu er helt forsvundet fra egnen, Outzen slægten i Roost. Gennem tre århundreder fra cirka 1500 til ca. 1800 frembragte den 10 herredsfogeder og birkedommere, 3 toldere, 1 skovrider og 3 præster foruden giftermål ind og ud af slægten til lignende standspersoner.

I tidens løb ejede Outzen slægten først og fremmest Roost Fogedgård, der formentligt har andraget omkring 540 hektar på dens højdepunkt, ${ }^{2}$ Musvang i Toftlund sogn, Møllegården i Toftlund og Hyrup skov. I perioder havde den af egnens større ejendomme fæstet Gjelstoft under Gram gods, Nitriskjær og Gammelskov i Agerskov sogn og ved sidegrene af slægten Brøns mølle, Toldergården i Brøns og Holmgaard ved Brøns.

I de tre århundreder var den $\mathrm{i}$ slægt med og indgiftet $\mathrm{i}$ de kendte storbondeslægter Astrup i Brøns sogn, Nissen på Hajstrupgård i Bylderup sogn og mange flere. Slægten var ikke alene rig på jordegods, men også på penge, og den forstod at bruge dette værktøj på rette tid og sted. Den forstod også det nødvendige $\mathrm{i}$ uddannelse og viden, flere af dem studerede og fik juridisk embedseksamen. De talte og skrev flydende dansk og tysk. Som unge var de ofte ude at rejse for at se verden. De levede med maner. Det store stuehus på Fogedgården står endnu, men møbler og papirer er enten spredt for alle vinde eller gik tragisk til ved en brand i $1848 .^{3}$

Outzen slægten holdt sig noget afsondret, en slags fornemhed. Der er meget lidt overleveret om slægtens indre liv, få var rigtigt venner med dens medlemmer. De drak vin, fik tøj syet i købstæderne, holdt standsmæssige køretøjer. Venne- og bekendtskabskredsen var ligestillede, og dem var der ikke mange af på egnen, de måtte søges på store gårde og i købstæderne.

Outzen'erne havde sans for mere end dagen og vejen. Prægtige epitafier og gravstene fortæller om flere af dens navne. Rundhåndede gaver til sognekirken i Arrild berettes der endnu om på kirkeloftets bjælker og i kirkebogen, men underhånden skumledes der over magtbrynde og "indhalenshed «, det sønderjyske udtryk for begærlighed efter penge. Outzen slægtens magt beroede på penge og jord og embede, dens minde findes i tingbogen, men ikke i slægtsbibler, breve og dagbøger.

Det er næsten ikke at forstå, at en så betydningsfuld slægt helt er forsvundet ud af vor egns historie, men væk er den. Tilmed var den kun en af mange stærke og indflydelsesrige slægter over hele herredet, men særligt i Roost. Disse slægter fik et navn med på vejen af pastor Anders Th. Ørbech, sognepræst i Arrild sogn, også et sagnomspundet navn. Han kaldte dem »de 
store Rooster “, og Jørgen Fausbøl på Branderup mølle, selv ud af en lignende slægt på Mandbjerg skrev, at disse "store Rooster " havde siddet slægtled efter slægtled på deres stavne og nydt alle livets goder.

\section{Slægten Outzen}

Adelstiden i Roost udløb i slutningen af 1300-tallet. Man kan følge nogle slægtninge til de kendte navne på de to borgsteder, men de bor andetsteds $i$ landet og interesserer sig kun for denne egn i forbindelse med den kongelige lensmand Valdemar Sappis store og komplicerede dødsbo.

Få årtier senere begynder en storbondeslægt på Rømet i Toftlund sogn at gøre sig gældende i Nørre Rangstrup herred. Foruden den gode Rømetjord ejede den Musvang, der var en typisk enggård. I skatteværdi var den samlede ejendom ansat til 2 plove eller en sjettedel af hele Herrested eller Toftlund sogns skatteværdi, hvilket er ret enestående.

Den første kendte af slægten er sandsynligvis født $i$ slutningen af 1300 tallet og kan muligvis have heddet Holden Pedersen. Hans søn hed Peder

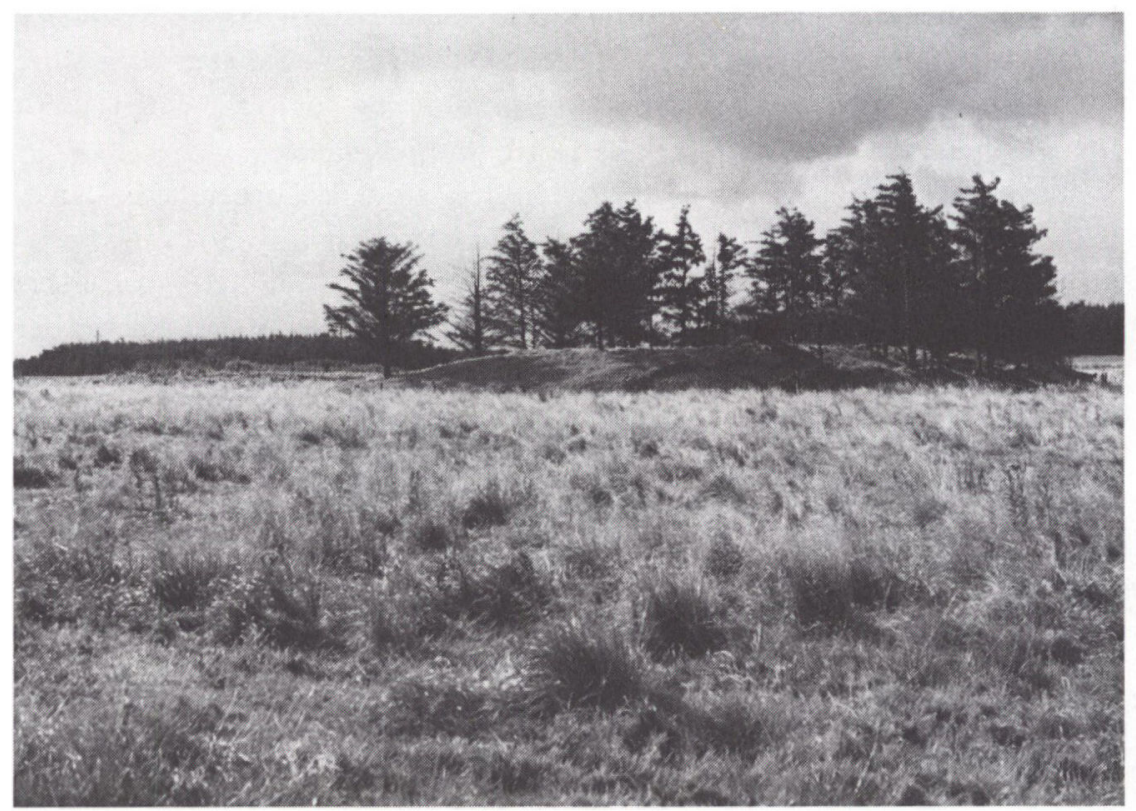

Voldstedet Sondervold i Roost enge, Arrild sogn, i modsatning til Norrevold starkt forstyrret i ärhundredernes lob. Om dette voldsted har haft tilknytning til en bestemt gärd $i$ Roost, har endnu ikke kunner afgeres. 
Holdensen og var herredsfoged i Nørre Rangstrup. Han solgte Rømet med Musvang i 1444 til klosteret i Løgum og flyttede en halv snes år senere til en anden af klosterets gårde, der kan have omfattet hele Branderup og Refslund. Sønnen Hans Pedersen i Branderup efterfulgte ham som herredsfoged og sønnen Tersten Pedersen i Roost blev sandemand (en slags domsmand, der skulle udfinde sanden, d.v.s. sandheden på tinge). ${ }^{4}$

Tersten Pedersen kan muligvis have været gift med en datter af en Skytte Owe i Stenderup, der optræder som vidne ved Peder Holdensens ejendomssalg til klosteret. Stillingsbetegnelsen kunne tyde på en hertugelig embedsmand som vildtfoged eller skovfoged. Benævnelsen alene ved fornavn tyder også hen på en fremtrædende personlighed. Tersten havde flere børn, her næunes kun Owe Terstensen, der ejede den senere Fogedgård i Roost og muligvis også Roostgård. Han må være født endnu i 1400-tallet og har levet til henimod midten af 1500-tallet, idet han er næunt i et skatteregister i 1542.

Owe Terstensen lod sine sønner døbe med efternavnet Owsen eller Outzen. En af dem hed Mads. Han ejede Roostgård og blev stamfader til den berømte Rostgaard slægt. En anden, Hans, fortsatte på Fogedgården og blev herredsfoged. Han levede fra 1518 til 1589 og nød stor bevågenhed hos amtmænd og hertuger. Han siges således at have modtaget træbestanden $\mathrm{i}$ Hyrup skov som en hertugelig gunstbevisning.

Det er før kirkebøgernes tid, og af Hans Outzens børn kendes egentlig kun sønnen Hans Outzen den Yngre, der levede fra 1556 til 1609. Det er sandsynligt, at der har været flere børn, der kendes samtidigt en Jes Outzen i Roost. Meget tyder på, at en datter, hvis navn ikke kendes, har været gift med herredsfogeden i Hviding herred Anders Nielsen, der levede fra omkr. 1543 til 1620. Hans Outzen den Yngre var gift med en datter af herredsfogeden i Slogs herred Hans Nissen på Hajstrupgård, der var søn af den berømmelige herredsfoged på Urnehoved ting, Nis Henriksen, der måtte flygte for livet med pileskud i kappen.'

Hans Outzen den Yngre og hans hustru Marin eller Maren lod sig minde på en stor smuk gravsten, der ligger $i$ indgangen til Arrild kirke. Stenen bærer Outzen slægtens våben: En okse. Dette våben antog Rostgaard slægten også, da den blev adlet, og med god grund, da den jo egentlig var ud af Outzen slægt.

Hans Outzen den Yngre havde efterfulgt faderen i embedet som herredsfoged i Nørre Rangstrup fra faderens død i 1589 til sin egen død i 1609. Som foged fulgte derefter en svigersøn, Jørgen Frederiksen, der var gift med en datter af Hans Outzen den Yngre, men hvis navn ikke kendes. Jørgen Frederiksen var foged til 1640 og efterfulgtes derefter af en Hans Hansen, der må have været søn af Hans Outzen den Yngre, men som mærkeligt nok ikke 
findes med Outzen efternavnet. Hans nøjagtige årstal kendes ikke. Det antages, at han er død omkring 1657.

Årene fra 1658 til 1661 var strenge krigsår i hele Nordslesvig. Først i 1662 var der skifte efter salig Hans Hansen og en Maren Hanses. Hvem hun var,

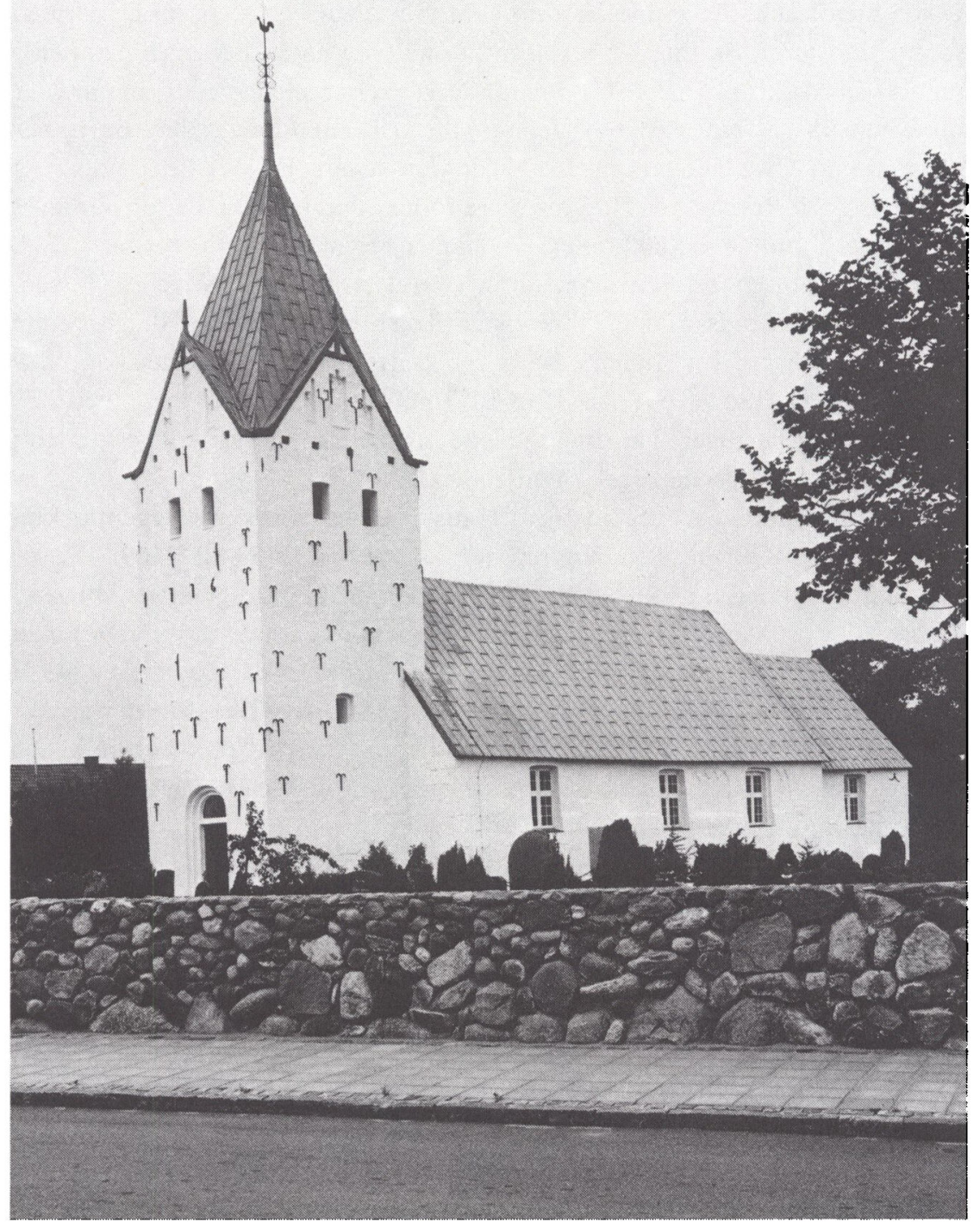

Arrild kirke, hvor inskriptioner og gravsten minder om den betydningsfulde Outzen slagt. 


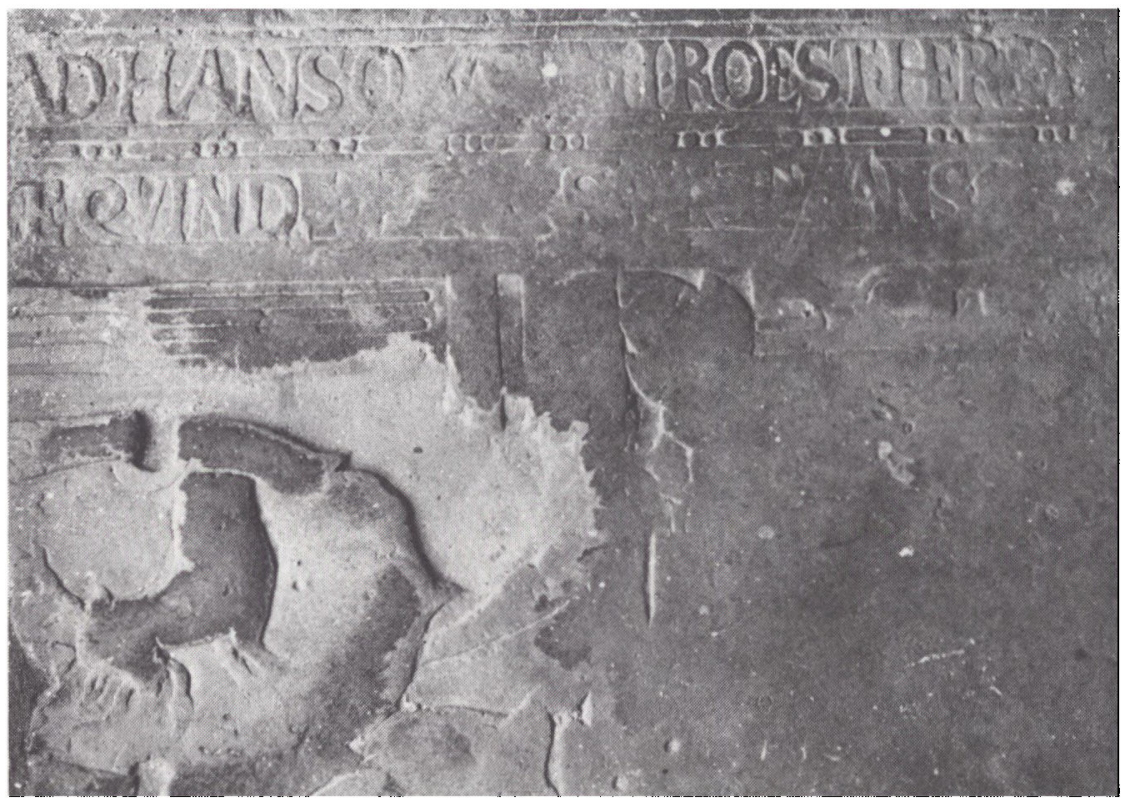

Gravsten over Hans Outzen (1556-1609) herredsfoged i Norre Rangstrup herred og hustru Marin eller Maren, fodt Hansdatter fra Hajstrupgàrd. Stenen ligger $i$ kirkens dor som fodsten. Hans Outzens våben (en okse) er skjult. Marin Hunsdatters slagtsvåhen (en springende hjort med en slange i munden) er cndnu tydeligt.

kan heller ikke nøjagtigt afgøres. Hun kan have været Hans Hansens kone, men muligvis også hans moder, der kan være død i en høj alder. Der foreligger et meget omfattende og velbevaret skiftedokument, der tilskøder Fogedgården i Roost og Musvang med alle tilliggender til en ny Hans Outzen, der kommer fra Brøns og er søn af herredsfoged Hans Andersen, der igen er søn af herredsfoged Anders Nielsen, der tidligere er nævnt. Tilmed havde denne Hans Outzen også en slægtsforbindelse til Roost slægten på mødrene side, idet denne var af Nissen slægt på Hajstrupgård. Slægtsskabet har således sandsynligvis været dobbelt, og $\mathrm{i}$ hvert fald har manden fra Brøns båret Outzen navnet. Af familiemæssige grunde kan han have været forudbestemt som tronarving til herligheden i Roost. Herpå tyder også hans våben, der bestod af Outzen slægtens okse og Hviding slægtens halve lilje og to roser.

Der udspandt sig en heftig arvestrid; men Hans Outzen fra Brøns havde kongelig bevågenhed og har sandsynligvis været meget pengestærk og kunnet udnytte konjunkturerne efter den forfærdelige svenskekrig. Han fik sin vilje både med hensyn til gårdene og en anpart af Hyrup skov. Han forblev boende i Brøns og sad i lange tider på en række embeder i begge herreder Hviding og 
Nørre Rangstrup. Han fremtræder ved mange lejligheder som en myndig og selvbevidst mand og lod sig minde sammen med hustruen Dorthe, født Jesdatter og sandsynligvis herredsfogeddatter fra Frøs herred, ved et smukt epitafium i Brøns kirke. Man fornemmer, at de store har kendt hinanden.

Der var mange børn i Hans og Dorthe Outzens ægteskab, her skal kun nævnes sønnen Detlef Outzen, der var født omkring 1650. Han efterfulgte faderen på de mange gårde i Brøns og Roost og $\mathrm{i}$ en del af embederne, han var således ridefoged $\mathrm{i}$ mange år $\mathrm{i}$ begge herreder. Alt tyder på, at han har været meget velhavende. I de vanskelige efterkrigsår, hvor mange gårde lå øde, d.v.s. ubeboede og udyrkede, drev han en regulær forretning ved at fæste sådanne gårde af kongen mod at beslå dem med besætning og inventar og $\mathrm{i}$ det hele taget bringe dem på fode igen. Det gjaldt så store gårde som Nitriskjær og Gammelskov i Agerskov sogn, Gjelstoft i Gram sogn og antageligt også Møllegården i Toftlund by. ${ }^{6}$ En del af jorden var faldet $i$ hede igen, og Gjelstofts enge var stærkt vandlidende, fordi sluser og grøfter ikke var passede. Detlef Outzen magtede let disse investeringer, der gav stort udbytte.

Detlef Outzen var gift med Herlich (Helvig) Høyer, præstedatter fra Ladelund i Sydslesvig. Sandsynligvis er han den af alle Outzener, der har siddet $\mathrm{i}$ de tryggeste kår. Han var som sine forfædre højt agtet. I årene 1677-79 var han således midlertidig amtsskriver i Løgumkloster amt, og han nød ved sine mange ejendomstransaktioner en helt usædvanlig bevågenhed hos konge og embedsmænd.

Endelig kan man indirekte erfare om et ganske bestemt virke, Detlef Outzen har udøvet. Både hans forgæengere og hans efterkommere har sikkert også dyrket pengeudlån; men hos ham kan det eftervises på papiret. Da Haderslev amt $i$ begyndelsen af 1700-tallet søgte at få bund $i$ de mange skatterestancer helt fra svenskekrigenes dage, måtte skyldnerne afgive oplysninger om deres samlede gældsforhold. Her ses ridefogeden i Roost nævnt gang på gang og med betydelige beløb. Man kan undre sig over, hvordan slægtens rigdom på kapital er kommet til veje; men vitterligt er det, at her støder vi på en af de bondebankiers, der gennem århundreder har varetaget pengeformidlingen helt op til den tid, hvor banker og sparekasser vandt indpas også på landet. Investeringer på spekulation i "ødegårde “ er allerede nævnt, men Detlef Outzen forstod også at holde den store gård i Roost i orden. Den var sommer og vinter beslået med en stor besætning af stude. Der blev dyrket en del havre til hestene, og der var formodentlig malkekøer og svin til gårdens eget betydelige forbrug, men næppe med salg for øje. Roost Fogedgård var hovedkvarter for Detlef Outzens virke. Den var en stor firlænget bygning om en meget stor gårdsplads, hvor der var mødding. 
Slagien Rostgaards váben, en okse, er en fortsattelse af Outzen-slagtens våben.

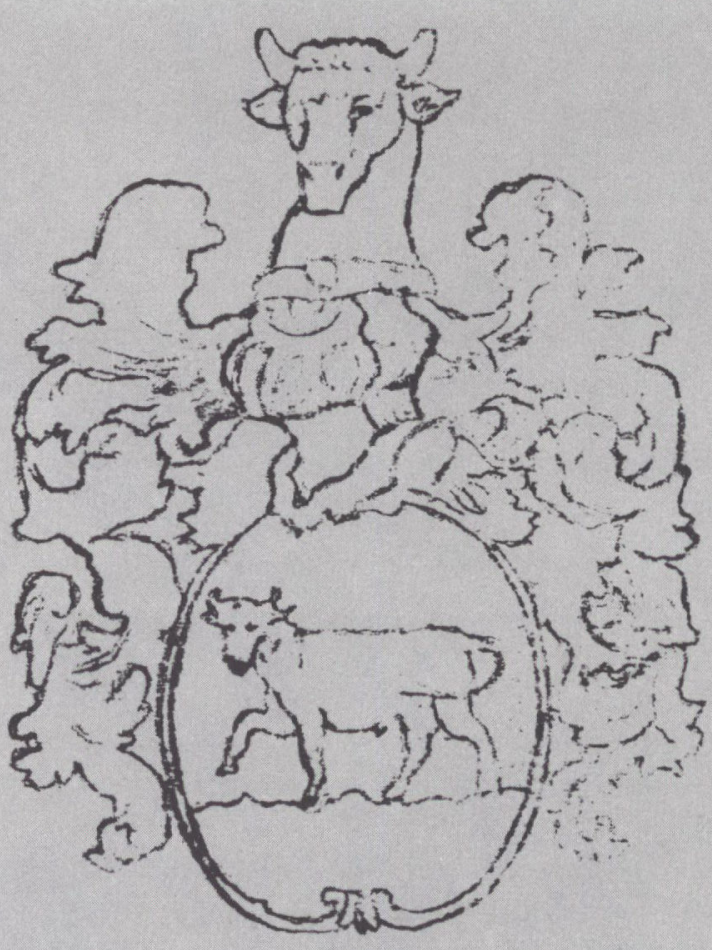

ROSTGRARO

Der kunne køres direkte gennem bygningerne gennem to store porte. Som vanligt var, udgjorde stuehuset den ene længe.

Indhuset eller stuehuset er den dag i dag imponerende. Det har aldrig kunnet siges med sikkerhed, hvornår det egentlig er bygget. Meget taler for, at det er Detlef Outzen, der enten har bygget gården op fra grunden eller ombygget et ældre stuehus. Tømmeret hentedes i egen skov i Hyrup, og ældre bulhusvægge erstattedes af grundmur. Den lange facade til haven blev brudt af en stor frontispice. Omtrent samtidig skal den Rostgaard Evaldske gård have fået bulhusvægge erstattet af teglstensmur. Roost by er hurtigt kommet til kræfter efter krigen. På Fogedgården nævnes i 1706 et "Kongens kammer «, et middelalderligt levn fra den tid, hvor Kongen rejste på "gæst « $i$ alle sine riger og lande og skulle have husly og forplejning, hvor han kom. At dette "Kongens kammer« netop fandtes på Fogedgården, giver et interessant 


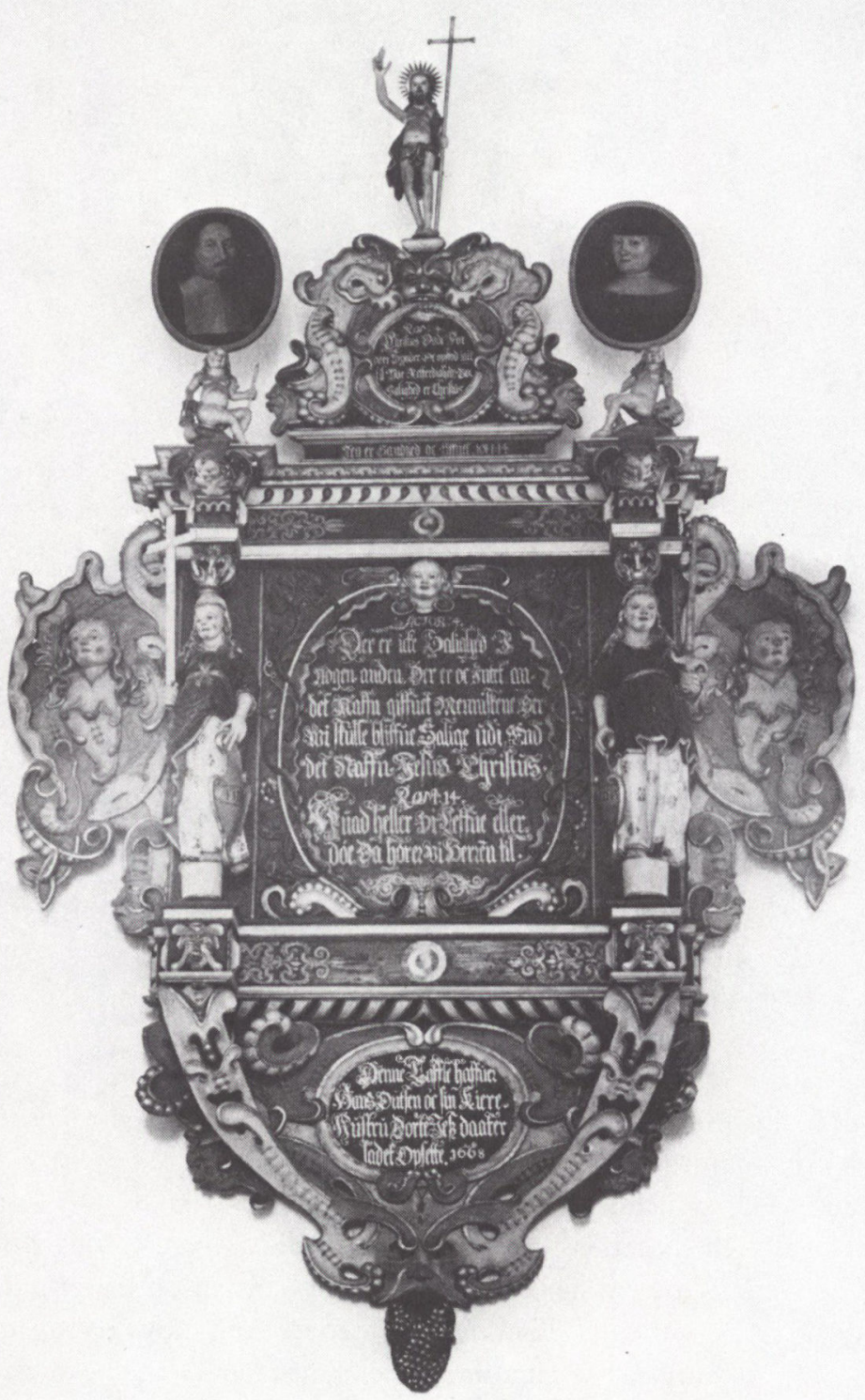

Hans Outzen (fra Brons) og hustru Dorthe Jesdatters epitafium i Brons kirke. 


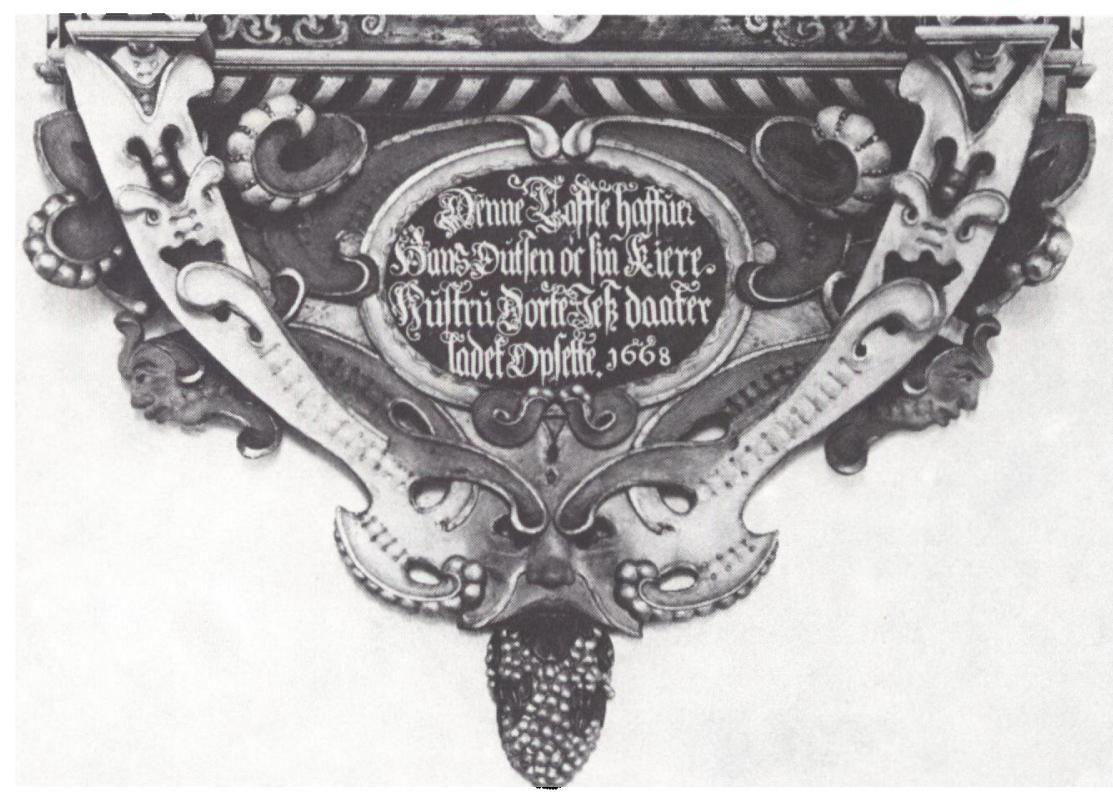

Epitafiets nedre del med indskriften: Denne Taffle hutfuer Hans Outzen og sin Kicre Hustru Dorthe Jesduatter ladet opsette 1668.

fingerpeg om gårdens betydning helt ned i middelalderen og måske endnu længere tilbage.

Detlef Outzen havde sind for andet end sit eget. En loftsbjælke i Arrild kirke fortæller, at kongelig majestæts ridefoged i Hviding og Nørre Rangstrup herreder i 1700 lod disse bjælker oplægge. Kirken har altså fået nyt loft.

Detlev Outzen døde i 1721 og efterfulgtes af sønnen Hans Outzen på Roost Fogedgård og på Musvang. Han blev husfoged i hele Haderslev vesteramt, et meget stort embede. Hans Outzen var gift med Anna Mechlenburg, datter af sognepræsten i Arrild, Christian Mechlenburg. En af hans brødre, Christian, blev sogneprast $\mathrm{i}$ Toftlund sogn, og en søster Ingeborg blev gift med sognepræsten i Branderup sogn, Nicolaus Freuchen, senere provst i Nørre Rangstrup herred.

Hans Outzen var født i 1687 og døde som 68-årig i 1755. Blandt hans mange hverv ofrede han særligt kirkeværgeembedet ved Arrild kirke omhu. I hans tid fik kirken nye klokker efter en stor indsamling, som han ydede et klækkeligt bidrag til. En anden bjælke i Arrild kirke fortæller, at i 1747 lod kirkeværgen Hans Outzen af Roost lofter og pulpitur "staffere«, d.v.s. male og dekorere. 


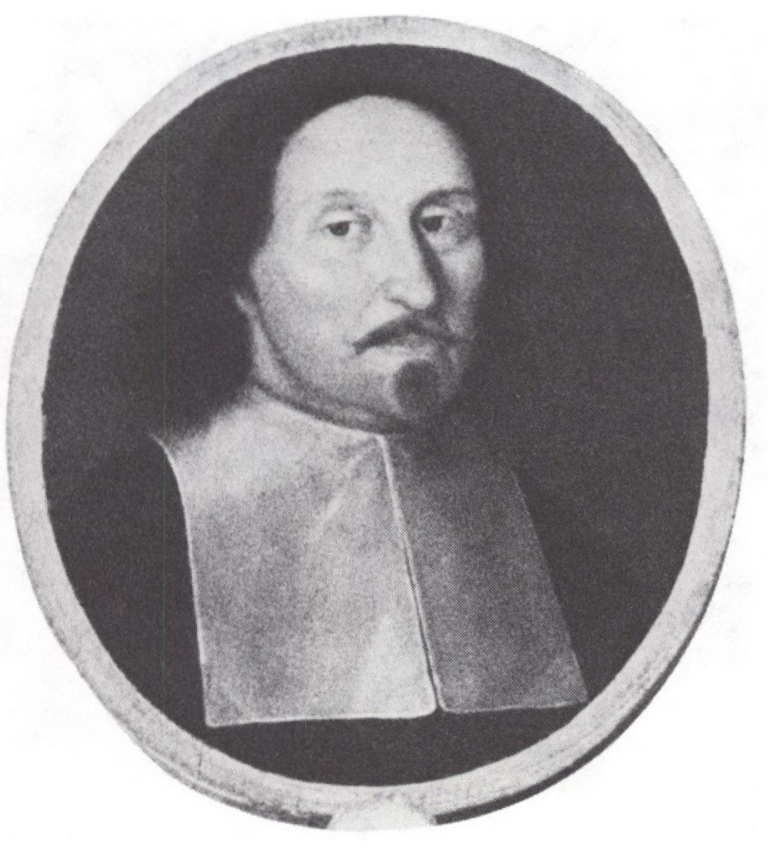

Ridefoged $i$ Hviding og Norre Rangstrup herreder Hans Outzen i Brens' portrat pd epitafiet. Ansigtstrakkene siges at have varet karakteristiske for Outzen slagtens mand.

Hans Outzen var en moderne indstillet mand. I hans tid begyndte Roost så småt at udskifte fællesjorden og begyndte med at dele en fælleshede i 1723. Det er meget tidligt sammenlignet med andre egne af Sønderjylland, og eksemplet dannede hurtigt skole.

Det er bemærkelsesværdigt, at Hans Outzen lod to af sine børn studere. Den ældste Detlef, født 1725, blev cand. jur. og i 1749 advokat. Senere blev han birkefoged i Løgumkloster birk og købte Fårgård, hvor han døde i 1783. Hans søn Hans Outzen blev efter en embedsmandskarriere herredsfoged i Slogs herred fra 1798 til 1804, det herred, hvor Nis Henriksen havde varet foged. Ringen sluttedes.

Den yngre søn Christian Outzen, den anden af Hans Outzen på Roost Fogedgårds studerede sønner, var født i 1732, og det er ham denne artikel egentlig handler om.

\section{Christian Outzen (1732-1809)}

Da Christian Outzen blev født, var der gået mere end 300 år siden hans slægt trådte ind $\mathrm{i}$ historiens lys og blev bevaret på prent. Han var den 11 . i rækken, siden Peder Holdensens fader havde ejet Rømet i Toftlund sogn, og ni af disse slægtled havde levet og ejet gård og jord $i$ Roost. Når hans forfædre nævntes $i$ 
ord eller bogstav, skete med titel af kongelig foged. De tiltaltes på dansk med Hr., på latin som Dominus eller Domine og siden hen på fransk som Monsieur, og der hæftedes smigrende tillægsord på dem som "fornehme mand “, velfornemme og højædle. Man beundrede dem, smigrede dem, var vel også noget bange for dem. Kun få var venner med dem eller kendte dem meget godt. Der var anstand og afstand. Ligemændene søgtes uden for hjemstavnen. Den kongelige nåde dryppede jæunligt på dem. I 1697 havde deres gård endda fået frigårdsrettigheder. De havde haft jord, penge og indflydelse nok til et adelsskab; men det har alligevel aldrig ligget for. De var selvbevidste bønder, men nok en herskerslægt, som vi aldrig hverken før eller siden har haft det i Nørre Rangstrup herred.

Et gammelt spørgsmål i alt bondeliv er, hvor længe en slægt kan holde sig

Fra engang i 1500-tallet horte trabestanden i Hyrup skov til Outzen slagtens besiddelser. Billedet viser den skoveng, der fra ost skyder sig ind $i$ skoven. Hovedindgangen til skoven lä forhen $i$ nordkanten af engen og ikke som nu overfor udflyttergärden, der sadvanligvis kaldes Fliegenheim. 
sund. Utallige gange er der begyndt med en slider, en sparer og en samler. Som oftest er der sluttet med en spreder. Træerne er ikke vokset ind $i$ himlen. Det hele er ikke endt på én hånd. Sådan skulle det også gå Outzen slægten, så mange og stærke grene, der end engang var på dens stamtræ. Om husfogeden Christian Outzen har haft flest penge og mest jord kan vanskeligt afgøres, men ingen af hans forfædre nåede den indflydelse, han fik lov at udøve $i$ henimod fyrre år, som den mand der drev udskiftningen igennem i Haderslev Vesteramt. Hans virke lod det store vesteramt skifte karakter. Lyngherrederne, som pastor P. Rhode skrev om i 1775 i Haderslev Amts Beskrivelse, blev nyopdyrkede. Landsbyerne blev tvunget udover de store øde overdrev, handel og håndværk fik grobund. Fællesskabets ophævelse skabte forudsætningerne for et tidehverv. Der satte forandringer ind, men en central bydannelse og højere skoler kom aldrig. Haderslev vesteramt var for amts- og centraladministrationen noget fjernt og ligegyldigt. Om det nogensinde er blevet andet, kan man betvivle. ${ }^{8}$

Christian Outzens livsværk er så meget mærkeligere, som det næsten ikke er kendt. Næppe var vesteramtets bønder blevet selvejere, så gererede de sig, som om de havde været det alle dage, og det havde nu kun de færreste. Nye stoute slægter skød op og kendes den dag i dag. En del faldt fra i tidens løb. Der er ikke mere Rieser i Stenderup og Hyrup, Ferslever i Ørderup og Toftlund, Krügere eller Lagonier i Hyrup, ejheller Fausbøller på Mandbjerg og i Branderup, Høyer i Agerskov, Arnum i Bovlund eller Zerlang på Skovsbjerg, men ellers taler man jo stadig drillende om landadel på denne egn. ${ }^{9}$

\section{Christian Outzens barndom og uddannelse}

Det er ikke svært at efterspore Christian Outzen i kirke- og tingbøger, fæsteprotokoller og især Haderslev amts regnskaber. Langt vanskeligere er det at erfare personlige træk og enkeltheder fra så at sige alle hans aldre. En del har kunnet findes i Jørgen Fausbøls bøger, især "Minder fra Branderup sogn og Roost “, en del er endnu bevaret som mundtlige overleveringer, selv om de fleste fortællere efterhånden er døde. En hjælp har det været, at den kendte pastor Nicolai C. Nielsen jævnligt interesserede sig for Outzen slægten omend særligt dens medlemmer på Løgumklosteregnen og i breve til Roostboere omkring 1910 søgte at erfare, hvad der endnu måtte leve af erindringer om den kendte, men forsvundne slægt. Sammenlagt er der en del oplysninger, omend de selvfølgelig er noget tilfældige og ufuldstændige og sikkert også ret usikre.

Christian Outzen var født den 31 . juli 1732. Kort efter 1740 skal den første 
skole i Roost være bygget, og i den har han gået en tid. Forældrene skal sammen med andre af byens gårdmænd have holdt huslærer. Desuden skal han efter tidens skik i kortere perioder have været i privatskole i præstehjem for at lære sprog og andre færdigheder. ${ }^{10}$

Både hans bedstemor og moder var præstedøtre. Uanset den store velstand og en ret storslået husførelse, skal der have været pietistiske strømninger $\mathrm{i}$ hjemmet, men de kan næppe spores at have præget den unge Christian. Faderens omfattende embeder har fordret mange rejser, også til købstæderne, og vel også nogen hjælp til regnskaber og korrespondance. Sønnen skal tidligt have ledsaget faderen på tinge og til stads. Allerede som dreng skal han have været ivrig rytter.

Christian Outzen blev konfirmeret i 1752, men må allerede inden dette år være blevet elev på latinskolen i Haderslev. Man kan undre sig over, at han ikke $i$ lighed med andre unge bogbegavede i Hviding og Nørre Rangstrup herreder søgte den mere ansete skole i Ribe, men faderens mange forbindelser til Haderslev, hvor amtsforvaltningen havde til huse, har nok været bestemmende. Hans forhold i skoletiden kendes ikke, men alt tyder på en lærenem elev. Han skal have haft godt logi i embedsmandshjem og brillerede ved jævnligt at føre hest med sig til rejserne hjem til Roost. For sligt findes jo også paralleller i vor tid.

I 1753 blev Christian Outzen student fra Haderslev og den 29. august samme år immatrikuleret ved Københavns universitet, hvor han studerede ret og økonomi. Efter fem års studium blev han juridisk kandidat. I alle studieårene skal han have haft en bekvem livsførelse, der var penge fra hjemmet. Derefter følger nogle år, hvor Christian Outzen ikke kan følges ud over, at man ved, at han efter tidens skik søgte ud på rejser $\mathrm{i}$ ind-og udland, havde mindre og kortvarige stillinger som »informator « $i$ gode hjem, men også i de kongelige kontorer. Der har næppe været tale om nogen formålsløs flakken, men snarere om en bevidst dygtiggørelse. Det er sikkert, at han har erhvervet indflydelsesrige venner $\mathrm{i}$ disse år, og at han har dyrket mangeartede interesser.

\section{Hjem til Roost}

Den 29. marts 1763 beskikkes Christian Outzen som husfoged i Haderslev vesteramt. Forspillet til denne ganske attraktive udnævnelse kendes ikke. Samme år afløste Olaus Zeuthen Georg Christian Hoffmann som herredsfoged i Hviding og Nørre Rangstrup herreder. Christian Outzen siges egentlig hellere at have villet have denne stilling, men skuffedes. Husfogedstillingen kunne i og for sig også have ført langt videre, posten i det store Haderslev 


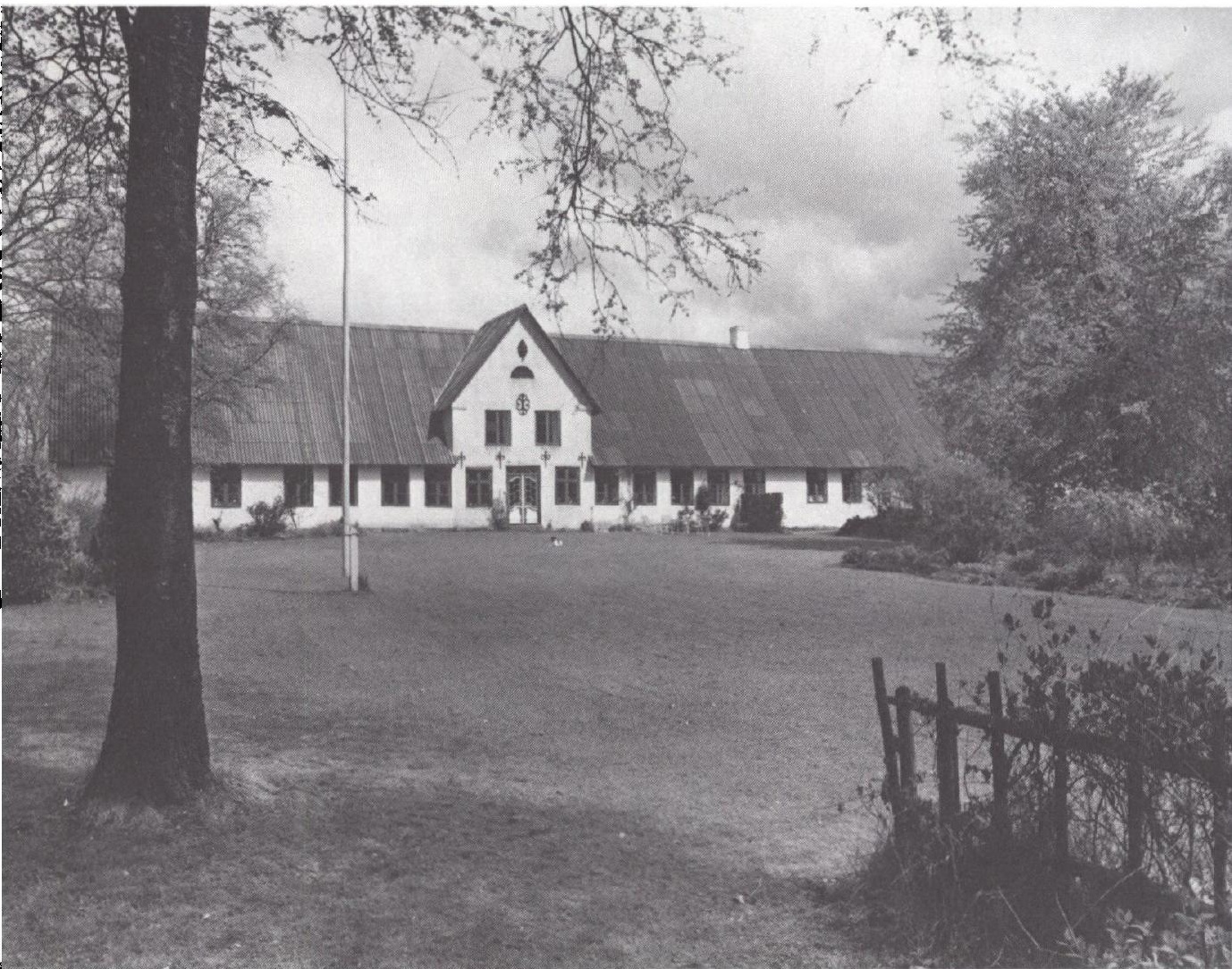

Fogedgärden $i$ Roost set fra haven. Det nuvarende stuehus er antageligt opfort af Detlef Outzen (o. 1650-1721) til aflosning af en aldre bulhushygning. Havedoren er af nyere dato, men i den oprindelige stil.

vesteramt (Hviding, Frøs, Kalvslund og Nørre Rangstrup herreder) var betydningsfuld. Alt tyder på, at Christian Outzen var forblevet arving også af sind til det store jordegods, og at han har tragtet efter tid og forhold på hjemegnen. Han kom jo også til at beklæde faderens embede som ridefoged og husfoged, det sidste endda i 35 år til 1798.

I hjemmet var moderen Anna, født Mechlenburg, endnu levende. Hun døde i 1770 og har formodentlig ført hus for sønnen, der var ugift. Ved hjemkomsten var han 31 år gammel med en uddannelse, der var noget ganske usædvanligt på egnen. Der stod glans omkring de to brødre Detlev og Christian.

I faderens tid havde man i Roost fået en forsmag på et vældigt tidehverv, 
der kom til at præge det store danske bondeland århundredet ud. Roost havde allerede i 1723 delt et stykke fælleshede, der hørte til Roost Nørreby, hvor Fogedgården lå. Man fortsatte så småt $\mathrm{i}$ de efterfølgende årtier og har faktisk været forbavsende fremsynede i den store og ellers såre konservative landsby. Foretagendet vakte megen opsigt. Det blev ligefrem besøgt i studiehensigt, og der blev henvist til det ved de mange svære tilløb, før udskiftningen virkelig blev sat i system fra omkring 1770 .

Christian Outzen må have haft god indsigt i tidens landbrug og hans juridiske og økonomiske uddannelse gjorde ham særdeles egnet til at være foregangsmand og drivkraft i den revolution, som udskiftningen og fællesskabets afløsning vitterligt var.

Ved moderens død må han have fået en husbestyrerinde eller $i$ hvert fald selskab i huset ved en ung pige fra nabogården, den nuværende Hoffmannsgave, Elizabeth Wilhelmine Hoffmann, datter af afdøde herredsfoged Georg Christian Hoffmann og hustru Marsilia, født Martensen. Med hende fik han en datter Anna den 8. februar 1775, medens brylluppet først stod den 12. maj samme år. Alligevel tituleres forældrene ægtefolk ved dåbstilførslen. Der kan

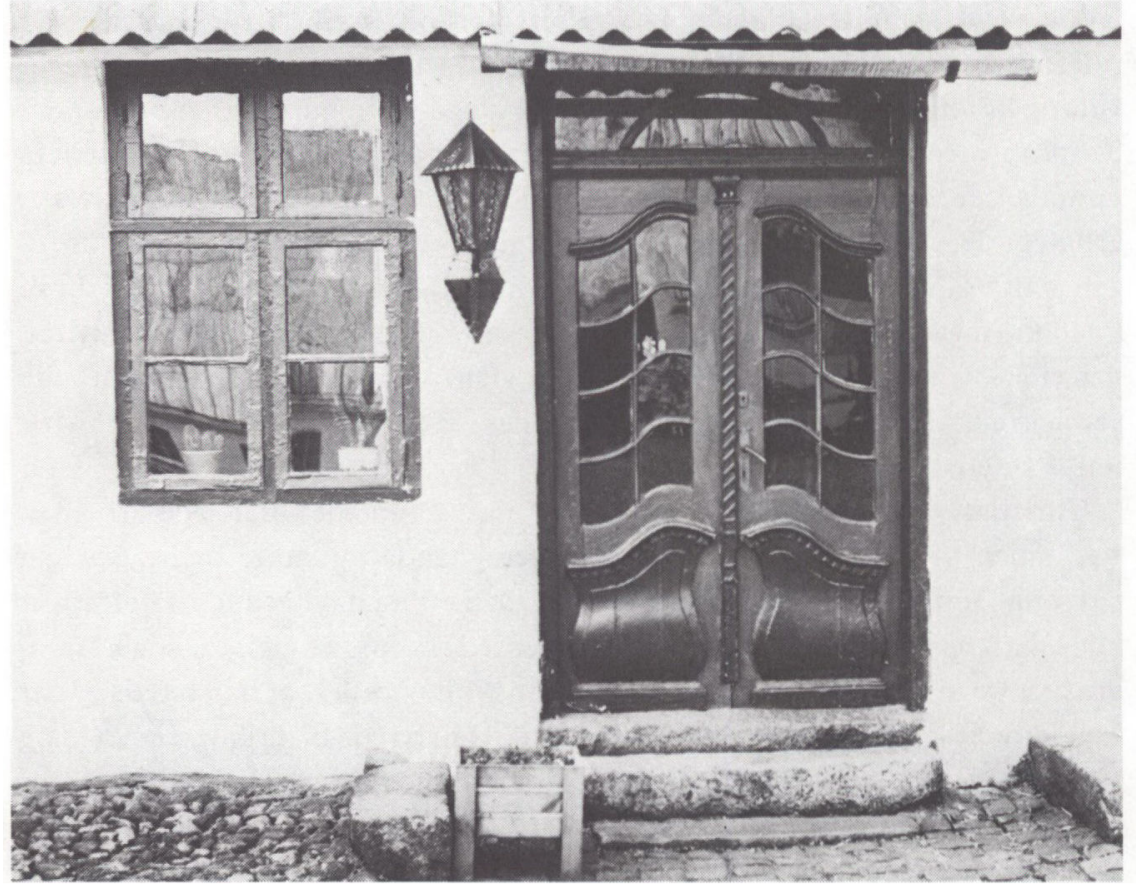

Der fra gärdsiden i barokstil i Fogedgården. To døre og flere vinduer gär tilbage til 1700-rallet. 
have været tale om en forudgående trolovelse, men nok også ligegyldighed overfor sædvane og decorum, der fortæller en del om den da 43-årige stormægtighed på Roost Fogedgård.

Ægteskabet varede til hustruens død i 1798 og var lykkeligt. Det begyndtes med et stort bryllup efter kirkelig vielse. Sognepræsten foretog vielsestilførslen til kirkebogen på latin for at hædre de implicerede slægters høje stand. Den 25. september 1776 fødtes en søn, Christian Outzen og den 30. oktober 1782 endnu en datter Marsilia, den sidste døde som spæd.

Et kig ind i det unge hjem i $1775 \mathrm{er}$ muligt. Nordmanden Søren Abildgaard foretog en stor Danmarksrejse for at søge og beskrive "antikviteter «. "Han besøgte Roost Fogedgård og berettede om en gæstfri modtagelse i det velhavende hjem. Christian Outzen foretog dette år en bemærkelsesværdig nedrivning af tårnbygningen på det store voldsted Nørrevold, selv om det må have ligget udenfor hans domæne. En del af stenene vides at være anvendt på et hus i Arrild; men en del er måske også fort til Fogedgården. Ved et hyggeligt sa mvær fortalte Christian Outzen den videbegarlige nordmand, at $i$ hans unge dage rejste man til Rømø, og ved ebbe kunne man gå over den sidste smalle pril tørskoet; der var lagt en stor sten midt $i$ vandløbet.

Det unge par på Fogedgården var populært og søgt. Det ses jæunligt som faddere ved standspersoners barnedåb nær og fjern, for eksempel hos ridefoged, fhv. ritmester Peter Bramsløw i Toftlund. Ægteparret færdedes vidt $0 \mathrm{~g}$ bredt $\mathrm{i}$ en eksklusiv vennekreds i Haderslev, Løgumkloster og Tønder og på store gårde. Der blev gjort genvisit på gården i Roost. Med få undtagelser var herligheden imidlertid lukket for egnens folk. Der holdtes et årligt gilde, hvor byens gårdejere var indbudt; men Outzens kom kun til gengæld $\mathrm{i}$ ganske få hjem. Hjemmets forhold og familiens liv holdtes skjult for den snævre hjemegn. Det var næppe snobberi, snarere en eksklusivitet, der ellers var så ukendt på disse kanter. Om der slutteligt var en virkelig vennekreds, kan være tvivlsomt. Storheden var forbundet med afsondring om ikke ensomhed.

Christian Outzen drev gården sagkyndigt, handlede og ledede arbejdet. Ved siden af mange penge var han nøjeregnende og vakte uvilje, da han påtvang Arrild kirke tømmeret til et nyt tårn efter en lynbrand i 1774. Hans lidenskab var heste og køretøjer. Han færdedes ofte i et giglignende køretøj med en hurtig hest forspændt. Jørgen Fausbøl fortæller, at han havde et par små lette heste, der kunne løbe en hare ind. Han havde både kaleschevogn og "lukket « vogn med kusk på forsædet og var en vanskelig mand at køre for.

Outzen slægten siges at have haft samme ansigtstræk fra generation til generation. Mærkeligt nok findes der næppe portrætter af dens medlemmer bortset fra to på et epitafium i Brøns kirke over Hans Outzen fra Brøns og 


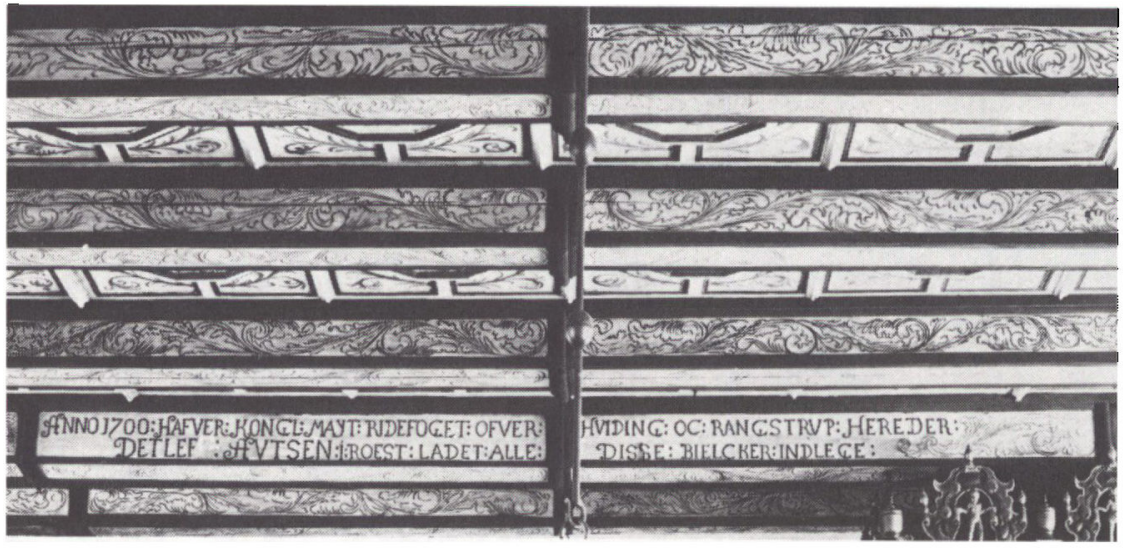

Inskription på lofisbjalke i Arrild kirke, der fortaller, at Detlef Outzen anno 1700 lod nye bjalker oplagge, en kostbar gave hentet i Hyrup skov.

hans hustru Dorthe Hanses, født Jesdatter. Christian Outzen siges at have været tidligt tyndhåret med kraftige ansigtstræk, lang næse og bestemt mund. Det kunne godt stemme overens med Brønsportrættet.

Så nær han kom på folk i de store jordfordelinger ved udskiftningen, forblev hans væsen køligt og afmålt. Han udtrykte sig jævnt og klart, men tit bidende ironisk. Bønders forhold til jorden forstod han, og han kunne tale deres sprog, når det skulle være. Man var imidlertid aldrig i tvivl om intelligens og position. Hans kritikere, og de fandtes, bebrejdede ham gridskhed og magtsyge. Han kunne trumfe tingene næsten foragteligt igennem, og han var ikke god som uven. Så lidt der kan bygges på, fornemmer man et køligt forstandsmenneske, der ud af egen fuldkommenhed gik henover mange af tidens skranker, men næppe over dens skel, hverken i marken eller $\mathrm{i}$ forholdet til mennesker. ${ }^{12}$

Christian Outzen vides at have bevaret flere af sin ungdoms interesser og at have fortsat mange forbindelser, han havde erhvervet i studietiden og årene derefter. Om han læste andet end faglitteratur og holdt aviser vides ikke, men han korresponderede en del. Manddommens indhold var jord og penge; men et nærmere indblik $i$ hans levned er ikke muligt. I 1848 brændte taget på Fogedgården og et meget stort arkiv, muligvis helt ned i de første Outzeners dage, blev ødelagt. Bøger, dokumenter og breve gik til grunde. De ville have kunnet berette det uoverskuelige ikke alene om den store slægt og dens sidste betydningsfulde repræsentant, men også om herredets forhold. Det var et endnu større tab end fjernelsen af herredets ældste tingsted i Rangstrup, der, hvis det var blevet bevaret, ville have været det eneste tilbageblevne i landet fra oldtidens dage. 


\section{Hr. husfogeden}

I "Beskrivelse over Tørning Lehn« 1815 opregnede topografen Knud Aagaard de verdslige embedsmænd i Haderslev amt: Amtmand, herredsfogeder, tingskrivere, amtsforvaltere, ridefogeder og husfogeder samt physikus (amtslæge), branddirektør o.fl.

Efter enevældens indførelse i 1660 var tendensen i forvaltningen gået mod embedsmænd, der havde regulær juridisk eller forvaltningsmæssig uddannelse. Det kunne næppe have truffet sig bedre, end at en mand, der var barnefødt i vesteramtet og var jurist, tiltrådte husfogedembedet, netop som dette vandt en helt overvældende betydning. Aagaard kalder nemlig husfogeden hovedperson $\mathrm{i}$ jordudskiftningssager, selv om herredsfogeden forrettede det skriftlige i disse sager. Det sidste var nok væsentligt; men endnu vigtigere var dog de forudgående forhandlinger, boniteringer og fordelinger. Husfogedens embedsområde var $\mathrm{i} ø v r i g t$ opsyn med vejvæsenet, medopsyn med skove, moser, damme og vandløb, tilsyn med visse bygninger, de kongelige møllers og gårdes udpagtning, tilsigelse af bønderne til ægter (pligtarbejde), udskrivning af militærleverancer o.a.

Haderslev amt var en efterkommer af to middelalderlige len Haderslev og Tørning, der på sin vis videreførtes som henholdsvis østeramt og vesteramt. Det første omfattede Tyrstrup, Haderslev og Gram herreder, selv om en del af det sidste herred skød sig ind i vesteramtets område ved Gram, Nustrup og Skrydstrup sogne. Vesteramtet var Hviding, Kalvslund, Frøs og Nørre Rangstrup herreder. Som helhed rakte Haderslev amt således fra Østersø til Vesterhav. Den nordlige del af Rømø var således haderslevhusisk, Ribe by lå som enklave i Haderslev amt, idet sognene nord for Ribe Farup og Kalvslund hørte til Kalvslund herred. Afstande og udstrækninger var af vest-eller nørrejyske dimensioner. De nødvendige amtsrejser til Haderslev fra vesteramtet var besværlige og meget tidskrævende. Amtets og herredernes interne administration hvilede tungt på bønderne. Vedligeholdelse af veje, broer, grøfter og hegn var en næsten uløselig opgave, alene den offentlige kørsel og brevbringen var et problem.

Haderslev vesteramt var hertugdømmet Slesvigs uland. Da Christian Outzen i 1763 tiltrådte embedet som husfoged, var der ikke sygehus, læge eller apotek uden for den ucentralt liggende amtsby. Adgangen til højere uddannelse var alene mulig for en lille priviligeret klasse af præster og storbønder. Postbesørgelse, forsyning med høkerivarer, isenkram og byggematerialer var mådelig. Der var næsten ingen adgang til anbringelse eller lån af pengekapitaler. Dertil kom de langvarige eftervirkninger af svenskekrigenes ødelæggelser. Skovene var næsten forsvundet, megen jord var igen 
faldet hen $\mathrm{i}$ hede. Erosion, sandfygning og udtørring hærgede. Den almindelige fattigdom trykkede til langt henimod 1800. Disse forhold er nok kendt, men aldrig gransket systematisk, selv om de spillede en rolle for den nationale, politiske og økonomiske udvikling helt op mod vore dage. ${ }^{13}$

1700-tallets mange krige og voksende folketal skabte imidlertid voksende efterspørgsel efter levnedsmidler med stigende priser. Vesteramtet havde en reserve i udstrakte enge, der ved systematisk overrisling kunne give grundlag for et stigende kreaturhold. Selv om svære kreatursygdomme gav tilbageslag, var der alligevel indtægter nok fra $1750 \mathrm{og}$ fremefter til at kunne betale investeringer, først $\mathbf{i}$ udskiftning og udflytning og derefter til en forbedret drift. De første udskiftningstiltag skete netop i engene, hvor det var åbenlyst, at den intensive drift forudsatte, at enhver ejer vidste, hvad der var hans, så det kunne holdes $i$ orden og fri af fællesdrift. ${ }^{14}$

Christian Outzen var fra barnsben fortrolig med engbrugets omstændigheder, men af endnu større betydning var, at slægten fra Detlef Outzens tid havde erfaring i drift af »enestegårde“, d.v.s. gårde, der lå i egen skelsat mark uden for landsbyernes fællesdrift.

Inskriptioner på pulpituret $i$ Arrild kirke fortaller om byggearbejder i Detlef Outzens tid.
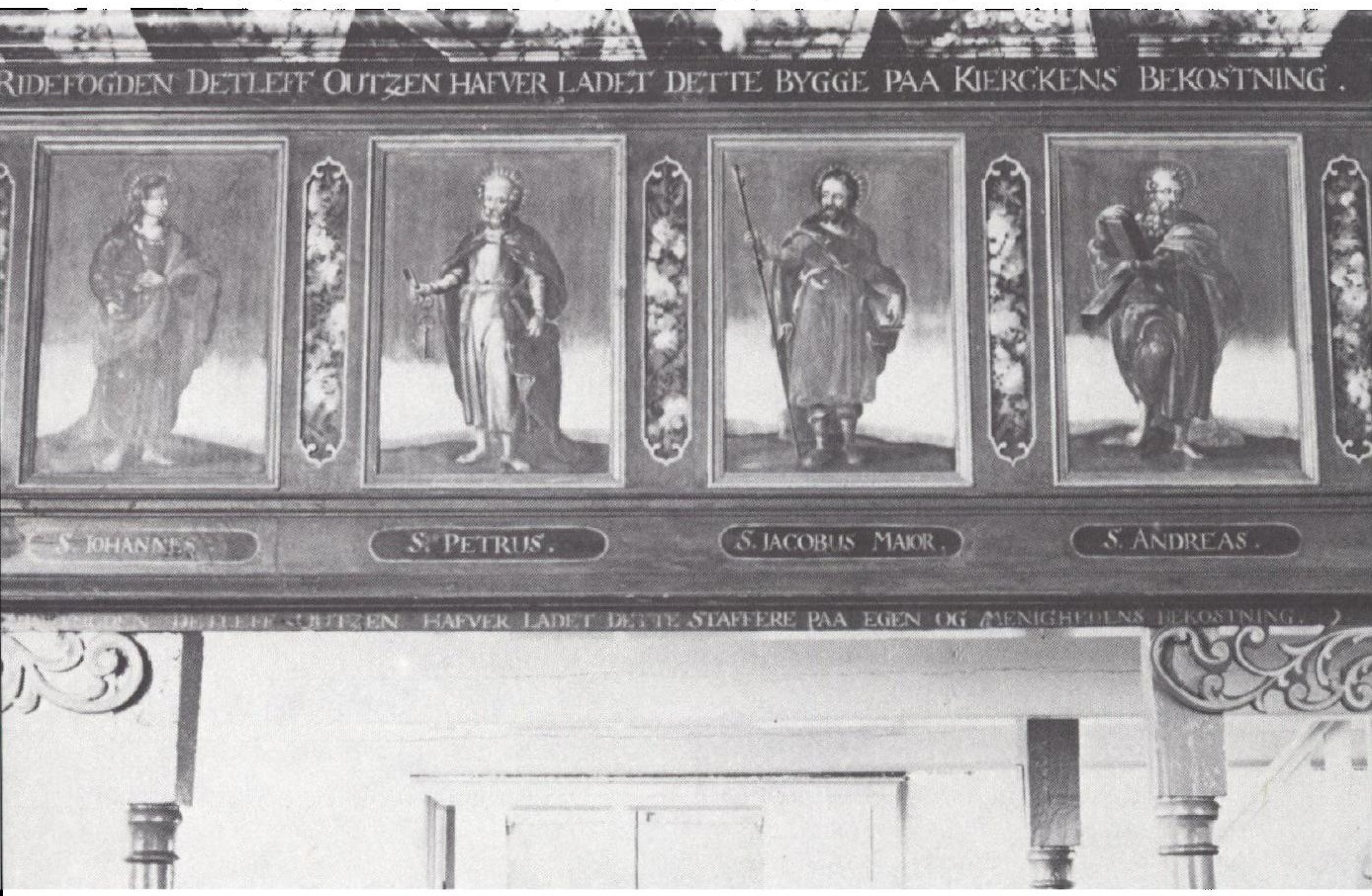
I Haderslev vesteramt kom man forholdsvis sent igang med udskiftningen, skønt der øjensynligt på et tidligt tidspunkt har været grobund for de nye tanker. I Roost stødte Christian Outzen således på en åndsfælle, Rasmus Holmer, én af byens største gårdejere, kniplingshandler og sandemand, der var dybt interesseret $i$ udskiftning og engdrift. De to fandt sammen med en trediemand, herredsfoged Olaus Zeuthen. Det blev et team, der på én gang kunne forberede løsningen af den store opgave, og som sikkert også øjnede de forretningsmæssige muligheder, en storstilet indsats i bondelandet på statens vegne kunne indebære.

Christian Outzen fik tidligt et godt renommé på amtshuset i Haderslev. Alt skriftligt arbejde fra hans hånd blev afleveret i pinligste orden. Han må have gennemtrawlet vesteramtet på kryds og tværs, ellers havde han næppe besiddet det grundige kendskab til de mange egnes omstændigheder, som han lagde for dagen få år efter. Ejendommeligt nok fik den første udskiftningslov af 1766 ikke de store følger i vesteramtet. Det var først loven af 1770 , der faktisk betød det ældgamle fællesskabs ophævelse, der fik betydning. Til gengæld kom de lokale ønsker om udskiftning da med en sådan voldsomhed, at det kan være svært at forstå, at datidens myndigheder i det hele taget kunne overkomme dem.

Ved denne lejlighed skal udskiftningsprocessen i Haderslev vesteramt ikke beskrives $i$ enkeltheder. Det er tanken at gøre det en anden gang, men selv et hastigt overblik støder på en stor hindring. Af Haderslev vesteramts husfogderis arkiv eksisterer næsten intet i vore dage, skønt det må have været meget omfattende. Også det skal være faldet som offer for branden på Fogedgården i 1848. Der findes en hel del delingsakter rundt omkring, noget findes på Landsarkivet i Åbenrå. En større eftersøgning på Rigsarkivet ville formentligt give nogle resultater, men som helhed er der kun et meget spredt og tilfældigt materiale tilbage.

Jorden havde hidtil været drevet i fællesskab. Det havde ført med sig, at den enkelte gårds andele i jorden var spredt på et stort antal agre, der ofte lå langt fra hinanden og gården. Den første opgave var at opmåle og bonitere al jord, dyrket og udyrket med hinanden. Der var dog nogle undtagelser. Skove og moser blev for eksempel opmålt og boniteret senere.

Principielt tilsigtede man, at hver landejendom skulle ligge i sin egen mark, og at denne så vidt muligt skulle ligge i et samlet stykke. I praksis lod det sig ikke altid gøre. En forudsatning var, at flest mulige ejendomme skulle ud af de tæt sammenbyggede gamle landsbyer og helst helt ud imod byskellene. Det forudsatte nedrivning og opførelse af bygninger, hvilket i sig selv var kostbart. 
Ved opmålingen og boniteringen blev jorden ansat $\mathrm{i}$ tre klasser:

1. Toftejord, der var den jord, der lå umiddelbart omkring den enkelte ejendom.

2. Ager og eng, der var den værdifulde dyrkede jord.

3. Hede, fælled eller "braxning “. Det var jord, der lå udyrket eller kun blev græsset af i fællesskab. "Braxning" var jord, der kunne dyrkes efter lange hvilepauser. Den var tit brakket, d.v.s. opharvet og holdt ren for ukrudt.

Stort set skulle den enkelte ejendom modtage de værdier samlet, som den hidtil havde haft spredt over mange steder. Enhver, der har haft med jordfordeling at gøre, ved, at der for det meste afgives god jord og modtages mindre god. Denne vanskelige proces kompliceredes yderligere ved forskellige hævdvundne omstændigheder. Den vigtigste var græsningsretterne, der var tillagt mindre brug, der var udstykkede fra den enkelte gård med et mindre areal, der var suppleret med græsningsret for et antal køer, får eller heste. Denne ret skulle nødvendigvis omregnes til jord ved udskiftningen.

Så vanskelige disse processer var, kom skatteberegningen til som kronen på værket. Det meste af landets skat lå på jordbesiddelse, og den måtte nu føres over på de sammenførte arealer og beregnes for den jord, der erstattede græsningsretterne. Skatten var i Sønderjylland pålignet efter den såkaldte

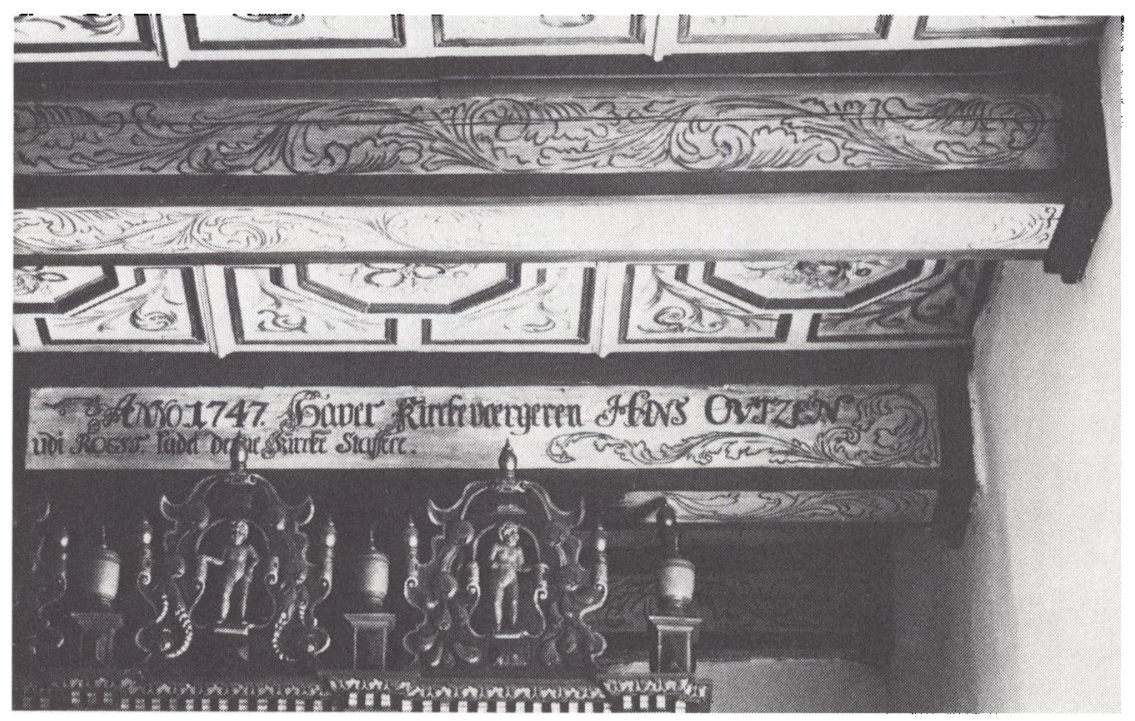

"Anno 1747 haver Kirckevargeren Hans Outzen udi Roest ladet denne kircke staffere" (male og udsmykke). Fra Arrild kirke. 
"plovtakst . Det enkelte sogn var ansat til et antal "plove«. Skatten var derefter fordelt på ottinger (der ikke betyder ottendedele), men var et udtryk for den enkelte gårds andel af landsbyens areal og bonitet. En otting var tilmed ikke et standardmål, men varierede fra by til by. I tidens løb var der sket talrige ændringer af den enkelte ejendoms dyrkningstilstand, bygninger og byrder $\mathrm{i}$ form af græsnings- og andre rettigheder. Den oprindelige skatteansættelse var derfor ofte helt forældet og fyldt med urimeligheder. Det var nødvendigt at regulere ansættelsen i forbindelse med udskiftningen. Det gik naturligvis ikke for sig uden strid. Den bonitering, der blev foretaget $i$ forbindelse med opmålingen af den enkelte parcel, var derfor egentlig en skatteansættelse og ikke så meget en gennemgående ensartet værdibedømmelse af jordens og dens eventuelle ydeevne.

Til disse store opgaver kom et utal af mindre, men tit vanskelige problemer. Der kunne være tale om vej- og stirettigheder, vandingsrettigheder for både dyr og enge, skelforhold og skrevne og uskrevne aftaler mand og mand imellem, der kunne have lange traditioner. Når det alligevel lod sig gøre at komme igennem, skyldtes det, at landboerne indså nytten af den store reform. Der var lidt offentlige penge at gøre godt med, men ikke så forfærdelig megen tid. Var man først begyndt på udskiftningen og koncentrationen til den enkelte ejendom, måtte man af hensyn til årets gang med sæd og høst se at blive færdig. Der hang mange løse ender og dinglede, og de krævede tålmodighed. En fast hånd, der styrede og pressede var nødvendig, for at den flydende tilstand kunne overstås, og denne hånd havde Christian Outzen.

Gransker man de gamle delingskontrakter, er det slående, at husfogedens styrke må have ligget på tre iøjnefaldende felter.

Delings- eller udskiftningsakten var i sig selv en protokol, der skulle rumme det fornødne, men ikke være for lang. Den blev jo læst som en bibel efter overstået udskiftning. Christian Outzens akter er skrevet med uforlignelig klarhed og fasthed. Kombinationen af juridisk uddannelse og praktisk landmandsindsigt kunne ikke være bedre.

For det andet er det enorme pillearbejde, som opmålingen og boniteringen var, foretaget med næsten ufejlbarlig grundighed. De gamle dokumenter er skrevet, udregnet og optalt med største nøjagtighed. De mange små individuelle enkeltheder, der hæftede ved så at sige hver lodsejer, er overvejet, gjort i penge eller jord og afgjort én gang for alle. Man ved, at mange af disse enkeltheder er blevet afviklet med hård hånd af husfogeden, det var absolut også nødvendigt, ellers ville man aldrig være blevet færdig.

Det tredie er den overordentlige ordenssans, som Christian Outzen har haft $i$ alle sine forhold. Det er ikke uden grund, at vesteramtets delingsakter blev fremhævet som eksemplariske vidt og bredt og jæunligt brugt som 
forbillede. Christian Outzen må have lagt en fast forretningsgang fra starten og haft alle formaliteter vel gennemtænkt.

Man undgik ikke stridigheder i vesteramtet, det gjorde man intetsteds. Alligevel var de forholdsvis få, men at træffe alt rigtigt første gang er ikke menneskeligt muligt. En af de værste ankesager var foranlediget af ritmester Peter Bramsløw på den senere fattiggård i Toftlund, Christian Outzens gode ven, der havde forset sig på den senere Herrestedgård $\mathrm{i}$ samme by. ${ }^{15}$

Der går mange historier om Christian Outzens medvirken ved udskiftningerne. Han kom som en herremand i et flot køretøj, der også havde plads til herredsfoged, skriver, landmåler og andet fint folk. Afstanden til folket blev holdt. Der blev sagt hr. husfoged, og det var nok også klogt. Jord og vand har altid kunnet bringe bonders blod i kog.

Hvordan vil I dele, spurgte han Branderups bymænd og tænkte her på de mange græsningsretter $i$ byen. Efter retfærdighed, hr. husfoged, svarede man skinhelligt og dog spydsk. Husfogedens windhalenshed « var velkendt. Retfærdighed, svarede Christian Outzen, hvad er det for et dyr? Æder det hø? - Meningen var naturligvis, at alle måtte bøje sig og vise god vilje. Opstyltet snak om retfærdighed var ganske uden interesse.

Hvad skal jeg med al den hedejord, skældte en af Hyrups bønder. Sælg den til en slider, svarede husfogeden, underforstået, at det var den pågældende lodsejer ikke.

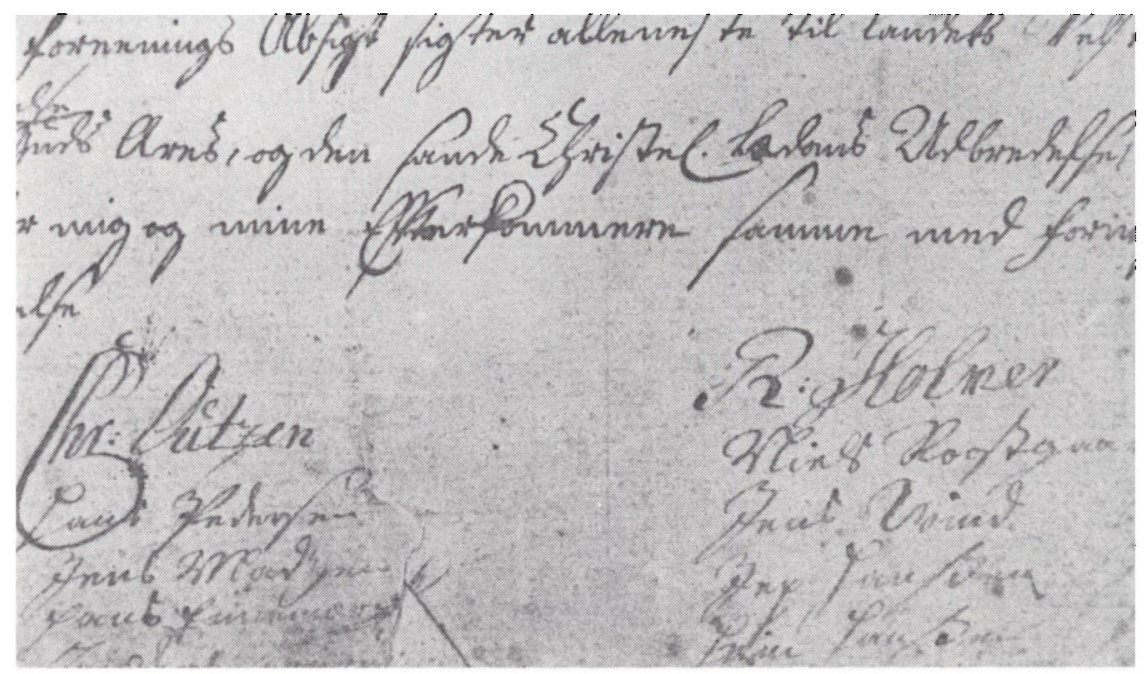

Christian Outzens og Rasmus Holmers underskrifter på et udskiftningsdokument fra Roost, dateret 31. marts 1771 . 
Da Roost Nørreby, Christian Outzens egen bopæl, blev udstykket, var der strid om eng og ager, skønt den Rooster jord ikke faldt hen i lyng, men vedvarende græs, et næsten ubetaleligt aktiv. Outzen slog af på engen og tog ager og fælled i stedet. Efter udskiftningen pløjede han fælledjord op, brakkede den et par år, gødskede den og såede kløver. Han gik et skridt videre og gødskede oven på græsjorden, et skridt endnu og pløjede store arealer op til korn. Det var i gårdens nordøstre hjørne, hvor han byggede en gård til, Skovlund. På den stod et par karle og tærskede vinteren igennem. Sidst i 1700-tallet steg kornpriserne, og husfogeden tvang gødningen fra vinterens store studehold på stald ud på de bedst egnede af den store gårds marker. Hans byfæller respekterede dygtigheden, men at han evig og altid skulle have ret og få ret vakte modvilje. Populær blev Christian Outzen ikke; men det tragtede han heller ikke efter. ${ }^{16}$

En vanskelighed, der næppe forstås i vore dage, er den forskel, der var på de enkelte landsbyer. For at nævne nogle få eksempler:

Gestrup havde god agerjord, noget krat, ingen mose, dårlige, men store enge.

Aabøl havde mager agerjord, hverken krat eller mose, men masser af eng, omend stærkt vandlidende.

Hyrup havde ret god agerjord og eng, men for lidt, overflod af skov og mose og en uendelighed af hedejord.

Roost havde alting med undtagelse af mose.

Hvor omhyggeligt skatteboniteringen end blev foretaget, var der forskel fra by til by, og den er faktisk bevaret helt op til vore dage, omend i afsvakket form. En stor hjælp ville det have været, om der havde eksisteret en ensartet bonitering i Sønderjylland i lighed med den danske hartkornsansættelse (selv om den også var forældet på udskiftningens tid); men den kom først senere. Om Christian Outzen har skabt sig selv en slags nøgle ved vurderingen af den enkelte jordparcel, kan ikke afgøres uden et meget tidskrævende studium af hans boniteringer, der blev udført ved hjælp af lokale sandemænd.

Udskiftningsprocessen strakte sig over det meste af tredive år og fortsatte efter 1800, f.eks. for mosernes vedkommende. Det første tiår fra 1771 til 1781 var den travleste tid. Selv med det tilfældige dokumentmateriale, der er til stede, kan man skønne, at der har været tale om et stort apparat, hvor ikke alene de offentlige embedsmænd har været travlt beskæftiget, men hvor landmålere og sandemænd har haft fuldt op at gøre. For Christian Outzens vedkommende har det givetvis været nødvendigt at have regulært kontorhold. Han må have ligget på landevejen tidligt og silde. Det er ikke muligt at skønne om antallet af udskiftningssager, han har deltaget i som husfoged. 
Det kan næunes, at små lokaliteter som Refslund i Branderup, Rømet $\mathbf{i}$ Toftlund, Gammelskov i Agerskov og mange flere havde hver deres selvstændige udskiftningsforretning. At mange byer som f.eks. Stenderup og Roost var delt op, og at hele reformen ofte var delt op i tempi, så endelig udskiftning og opmåling fandt sted mange år efter, at det første tiltag var taget. Visse byer kom sent med. Åbøl by f.eks. først i tiden 1794-97.

Om Christian Outzen fik nogensomhelst lokal anerkendelse, er tvivlsomt. De mange gange, han kort havde trumfet en afgørelse igennem, blev husket. Hans »indhalenshed « faldt også for brystet. Egentlig var han kun lønnet med faste beløb af amtet plus såkaldte sportler, d.v.s. gebyrer. Han wakkorderede “ imidlertid jævnligt om en fast sum for at køre hele retshandlingen igennem, der så straks kunne fordeles på lodsejerne. Det var i og for sig praktisk, og da han i så fald ikke satte noget igang, før pengene var der, vidste man straks, hvor man var, og skulle ikke slæbe med ikke opgjorte regninger $i$ årevis. Naturligvis satte han en sådan "akkorderet" sum så højt, at han var sikker på at få noget for sit arbejde. At han måtte holde kontor, svare de øvrige embedsmænd deres sportler og anvende tid og kræfter på arbejdet, havde man næppe forståelse for. Det var to tidsaldre, der stødte sammen. Hvorfor skal han, der har nok $i$ forvejen, have endnu mere, var et ikke uforståeligt synspunkt.

De tre amtmænd i Christian Outzens embedstid: Friederich von Klingenberg (1754-83), Christian Ludwig von Stemann (1784-89) og Johan Sigismund von Møsting (1789-1804) vidste alle at værdsætte den punktlige embedsførelse og den forbilledlige indsats $i$ udskiftningsreformen. Christian Outzen nød deres tillid og var på sin vis en lille konge i vesteramtet. Der blev trukket på hans viden og erfaring, både ved udskiftningsanliggender uden for vesteramtet og ved forhold $\mathrm{i}$ vesteramtet, der egentlig lå udenfor hans domæne.

Hans lange og fortjenstfulde virke opnåede endda anerkendende omtale af Christian Ditlev Reventlow i $1796 .{ }^{17}$ Alligevel er der over hans afgang noget uigennemsigtigt. Han gik som 65 -årig og skulle faktisk have kunnet sidde noget længere. Han skulle egentlig også have kunnet tilkomme noget mere ære. Der var $i$ hele hans embedstid tanker om en deling af Haderslev i et østerog vesteramt, med hver sin amtmand og separate administration. Det gav anledning til intriger, som kun kendes overfladisk. Man kan gisne, om der har været ønsker om hans ganske betydningsfulde embede, men noget sikkert kan ikke siges. Ejendommeligt er det imidlertid, at en stor del af husfogedarkivet med udskiftningsarbejdets store dokumentmateriale forblev på Fogedgården. Man må håbe, at grundigere arkivstudier ad åre vil kunne kaste lys over afslutningen af Christian Outzens lange embedstid. 
Fra den vide vesteregn blev der så vidt vides ikke nogen tak til embedsmanden og storbonden. Det ville vel også have været usædvanligt for tiden.

Udskiftningerne sidst i 1700-tallet var kun en begyndelse, processen fortsatte op gennem hele 1800-tallet for at afsluttes med det århundredes udstykninger. Ved mange lejligheder har man siden kunnet konstatere Christian Outzens forudseenhed. Mange af hans udskiftninger havde forberedt den næste eller de næste etaper. Da gårdene i Toftlund i midten af 1800-tallet blev tvunget ud af byen, fandt man det meget let at placere dem på de arealer, de havde liggende udenfor bykernen. Der havde været idé i hans tankegang, og den kan stadig følges i marken i adskillige byer og ved den store deling af hans egen gård i 1849. Han havde været forud for sin tid, og det bliver man jo sjældent populær ved.

\section{De sidste år}

Husfoged Christian Outzen har næppe erindret året 1798 som et af sine gode år. Den 20. december 1797 var der bevilget ham afsked fra embedet med en årlig pension af 150 rigsdaler. Afskeden havde været ærefuld, men hans lange embedstid og store fortjenester kunne dog have berettiget ham til en udnævnelse til kancelliråd som en hædersbevisning, ordener dryppede jo sjældent på bondestanden. Ansvaret og æren var borte, og pensionen var kun en klatskilling $\mathrm{i}$ forhold til de forgangne års rundelige indtægter.

En stor sorg traf ham, da hustruen døde den 26. september 1798. Hjemmet på Roost Fogedgård havde været anset og beundret; men der havde vel også været skår i lykken. Elizabeth Outzen blev kun 47 år. Et og andet havde vel også kikset i sønnens opdragelse, og trods gode landbotider sidst i 1700-tallet tyder noget på, at velstanden var i aftagen.

Christian Outzen følte sig skubbet ud. Der var ikke mere bud fra nær og fjern, hans ord var ikke mere lov. Han havde ikke mere med amtets embedsmænd at gøre. Det store rejseri, der både havde fængslet og trættet, hørte op. En begyndende døvhed gjorde endnu mere ensom.

Fra disse år haves kun mundtlige overleveringer om symptomer, årsagerne kan man kun gisne om. Forholdet til sønnen Christian Outzen kendes kun ganske overfladisk, og det må have været ret afgørende for fremtiden på den store gård.

Den ældre Outzen havde giftet sig ret sent. Hans søn var på kanten af at være et gammelmandsbarn, og tilmed fandt hans opvækst sted under faderens travleste år. Der kan have været knapt med tid og forståelse til arvtageren. Tilsvarende vandt moderen $i$ betydning, og sikkert med for- 
kælelse til følge. Om den unge Outzen af natur var veg, får stå hen. Det har aldrig været let at være en betydelig faders eneste søn. Men øjensynligt har der ingen tanke været om, at sønnen skulle gå i faderens fodspor og have en boglig uddannelse som supplement til bestyrelsen af den store formue eller som adgang til en offentlig position. Evnerne må ikke have ligget for.

Det siges karakteristisk, at faderen ikke ville stå rådet af, som det hedder oversat fra sønderjysk. Den ældre var fortsat manden på gården, hvor han havde stået dag efter dag på dørstenen og kommanderet med folkene og slået smæld med pisken. Sønnen forblev dreng i faderens øjne, og faderen huskes som »vrejen« i disse år. Først efter faderens død satte sønnen selvbo. En ung svigerdatter og en flok børnebørn kunne måske have forsonet den bitre gamle mand med livets gang.

Det er sikkert, at indtægterne ikke randt så rigeligt mere på Roost Fogedgård; men alligevel kan man undre sig over, hvad der drænede slægtens kasse. Med selskabelighedens og rejseriets bortfald efter Elizabeth Outzens død, blev husholdningen billigere. De store kriser udefra kom først efter den ældre Outzens død. Pengeudlånet gav skuffelser, men også først efter Statsbankerotten. Afsætning og priser var endnu gode i det første årti af 1800-tallet. Store investeringer og omlægninger var der ikke på gården. To forklaringer kan være mulige, enten deltagelse i tidens pengespekulationer, der sjældent endte godt, eller et lille, men støt årligt underskud, der slutteligt skulle opsummere sig til betydelige tal. Årsagen kan have været et stort og dyrt folkehold under en veg ledelse. Noget bestemt kan ikke siges.

Christian Outzen den ældre døde den 1 . december 1809, og da var han allerede så godt som glemt på den egn, hvor han havde levet så længe og øvet så stort et virke. De ældre $\mathrm{i}$ hans hjemby følte, at en tid gik i graven. Christian Outzen nåede for den tid en høj alder af 77 år, han blev gammel og for gammel, sagde man sidenhen. Hans død har næppe været nogen stor sorg; men det kan jo godt have svaret til hans forstandsprægede, usentimentale livsholdning. ${ }^{18}$

\section{Epilog}

Christian Outzen den yngre var født i 1776 og således 33 år ved faderens død. I mundtlige overleveringer er han beskrevet som »bløhjarte å forlajt “, det vil sige godmodig og overlæsset, og det var ikke de egenskaber, bestyrelsen af den store slægtsarv krævede i hans tid. Han havde ikke embede og indtægter til landbruget, der kort efter kom ind i svære vanskeligheder efter Statsbankerotten.

Det fortælles, at slægten Outzen i lighed med andre pengeudlånere enten 
fik en stak næsten værdiløse gamle pengesedler stukket ud i Statsbankerottens dage eller måtte se udestående fordringer nedskrevet til det ubetydelige, der endda var usikkert. Slægtens mange pengeregnskaber gik til ved branden i 1848, og der er næsten intet at bygge på med hensyn til Outzenslægtens pengeformue $\mathrm{i}$ disse år.

Værre var dog de prisfald og afsætningsvanskeligheder, der fulgte i bankerottens spor. Fogedgårdens og Musvangs drift var ensidig græsning af kreaturer med salg for øje, og driften lod sig vanskeligt omstille. Den ældre Outzen havde været noget inde på kornavl til salg, men kun for en lille del af den store ejendom i Roost. Engene kunne ikke pløjes. Der var ganske vist god høj jord; men en omstilling til markdrift ville have fordret mange heste og endnu flere folk. Smørsalg krævede staldplads til malkekøer og eget mejeri. Udvejen havde været en hård nedskæring af folkeholdet og egen arbejdsindsats og nøjsomhed, selv på herredets største gård. Den yngre Outzen kunne ikke skære igennem. Det var blødhjertetheden, han savnede overblik og uddannelse, og derfor var han overbebyrdet. Problemerne var ikke kun hans, de var alt stort landbrugs på den tid. På sin vis er det mærkeligt, at nedgangen ikke gik hurtigere end tilfældet var. Store gårde stod øde i disse år eller gik for en slik på tvangsauktionerne.

Megen lykke var der ikke til Christian Outzen den yngre. I 1817 var han blevet gift med Anne Marie Christiansen, der må være født i 1796, men hvis herkomst ikke kendes. Hun døde i barselsseng den 11. juli 1818, kun 22 år gammel, efter at have bragt et dødfødt barn til verden. Hvordan Christian Outzen så har indrettet sig, vides ikke; men Arrild kirkebog udviser en dåbstilførsel i 1823 for en ny Hans Outzen, søn af Christian Outzen og Anne Rostgaard Evald. Det samme gentager sig den 15. marts 1825, hvor parret får en datter. Den 2. juni samme år er der bryllup. Få uger efter dør den lille pige, der var døbt Anne Marie, og den 1. januar 1827 dør den unge kone, kun 25 år gammel.

Det er forståeligt, at Christian Outzen den yngre tabte al energi og livslyst efter så svære prøvelser, og at han "nedbøjedes«. Den 3. juni 1828 døde han, af hvilken sygdom kendes ikke, knap 52 år gammel.

Den lille Hans Outzen kom i huset hos morbroderen Niels Rostgaard Evald i Roost. Dødsboet solgte den store Roost Fogedgård med Musvang og træbestanden af Hyrup skov til brændevinsbrænder og branddirektor Hinrich Andersen Jessen af Tønder for 7000 rigsdaler kurant. Taksationssummen var 21.000 rigsbankdaler. Omregnet lå salgssummen under halvdelen af den offentlige vurdering; men nogen formue var endnu holden til det sidste skud på den gamle stamme.

Hans Outzen var en rask og kvik dreng. Jørgen Fausbøl fortæller om hans 
Hinrich Andersen Jessen (17751842) brandevinsbrander og branddirektor fra Tonder, der $i$ 1829 køble Fogedgärden. (Silhouetportrat).

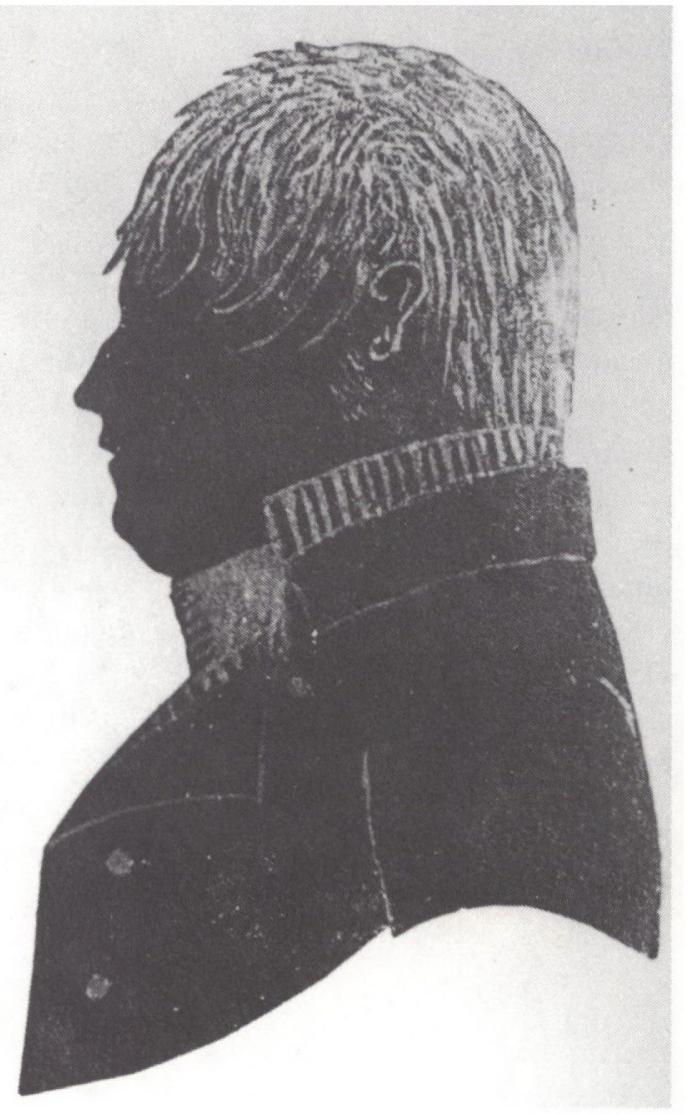

snarrådighed, da Roost' gamle skole brændte i 1834 . Hans Outzen snappede i en fart sine kammeraters huer, da børnene i hast måtte ud af skolen; men han glemte dog sin egen.

Den 30. oktober samme år døde Hans Outzen, 11 år gammel, vistnok efter en af datidens frygtede diftiritisepidemier, der jo ofte bortrev hele årgange af børn. Ulykken var fuldstændig. Den sidste Outzen var gået bort, efter at slægten havde siddet om ved 350 år på stavnen. Hvad under, at egnens tanker og tale kredsede omkring så megen ulykke og gisnede om dens årsager. Men også det kun for en stund. En ny kraftig slægt sad nu på Fogedgården og handlede og virkede som fortidens storbønder af den berømmelige, men uddøde Outzen slægt havde gjort det.

Glemselen sænkede sig forbavsende hurtigt over Outzenslægten. Om de tre sidste af dens mænd er intet minde tilbage i Arrild kirke eller på kirkegården. 
Nøglen til slægtens hemmeligheder forsvandt ved den store brand på Fogedgården i 1848. Ved den lejlighed blev "Kongens kammer " også nedbrudt.

I 1849 deltes Fogedgården $\mathrm{i}$ to næsten lige store dele. På den fraskilte jord byggedes gården Sandet, hvor en af Hinrich Andersen Jessens døtre og en svigersøn satte bo.

Fogedgårdens skæbnetime slog i trediverne, da så mange kørte fast. Gården blev i lighed med andre Roost gårde overtaget af Statens Jordlovsudvalg og for størstedelens vedkommende udstykket. Der blev en stamparcel på cirka 45 hektar tilbage. Faktisk var udstykningen så hårdhændet, og arronderingsforholdene så uheldige, at gården nok burde have været helt nedlagt. Når det ikke skete, skyldtes det det valdige bygningskompleks, som der blandt andet var føjet en ny og efter forholdene moderne stald til i 1920, Sønderjyllands smukkest sagde mange. Man veg tilbage for et sådant spild af værdier, og lod gården bestå, i svag afglans af, hvad den havde været. På sin vis tryllebandt Fogedgården i sin fornedrede stand også de efterfølgende ejere. Ikke alene drev de den godt; men de værnede på bedste måde om bygninger og omgivelser. Det mægtige indhus, den smukke have og den storslåede gårdsplads gør stadig et bjergtagende indtryk.

Kun få aner, hvor megen historie der gemmer sig bag gårdens navn og ydre. Her er kun gjort en ringe begyndelse.

\section{KILDER}

1. De slægtshistoriske oplysninger hidrorer $\mathrm{i}$ det væsentlige fra bibliotekar Carl Langholz, Skive, der har udarbejdet slægtstavler for flere af de kendte Roost slægter, herunder slægten Outzen. Desuden uddrag af kirkebøgerne for Arrild, Brøns m.fl. sogne. Holdensen slægten på Rømet og dens efterkommere $\mathrm{i}$ Roost er jævnligt nævnt i tingsvidner i 14- og 1500hundredtallene, hvoraf dokumenter vedr. salget af Rømet til Løgum kloster er gengivet $i$ Løgumbogen.

2. Et stort antal oplysninger har kunnet findes i private dokumentsamlinger $i$ Roost, Rurup. Branderup, Hyrup og Toftlund samt i Haderslev vesteramts husfogderis arkiv og i Nørre Rangstrup herreds tingprotokoller.

3. Agerskov Sparekasses historisk-topografiske bogsamling, der blandt andet omfatter et stort antal udskiftningsakter fra Haderslev vesteramt og dokumentsamlinger fra Nørre Rangstrup herred.

4. En række brudstykkeagtige oplysninger har kunnet findes $i$ private arkiver ud over Nordslesvig. Et eksempel er afdøde pastor Nic. C. Nielsens arkiv i Det danske Centralbibliotek i Flensborg og slægten Rostgaard Evalds arkivi Roost. En række breve fra pastoren til et medlem af slægten Rostgaard Evaldi 1909 stiller således mange direkte spørgsmål om de sidste tre generationer af slægten Outzen. Svarbrevene har desværre ikke kunnet opspores, og en omtale af en degneslægt Buch i Arnums værdi som umiddelbar kilde har heller ikke kunnet undersøges nærmere. Medlemmer af slægten Outzen ses ved talrige lejligheder omtalt som faddere, vidner ved retshandlinger, långivere og $\mathrm{i}$ anden anledning. 
5. Indtil for en halv snes år siden eksisterede en ret righoldig mundtlig tradition på Roost egnen om slægten Outzen helt ned til Detlef Outzen (o. 1650-1721). Oplysningerne herfra er imidlertid ofte spredte og tilfældige og undertiden indbyrdes modsigende. Det har således ofte været vanskeligt at afgøre om overleveringer vedrørte husfogeden Christian Outzen (1732-1809) eller sønnen Christian Outzen (1776-1828), og en række usikre enkeltheder har måttet udelades. Hjemmelsmænd har været Niels Jokum Hørlück og Peder Rossen, Rurup, Jeppe Madsen, Henrik Thomsen og medlemmer af slægten Rostgaard Evald, Roost, m.fl.

\section{LITTERATUR}

Jørgen Fausbøl: En Slægts Historie på Mandbjerg. 1909. Minder fra Agerskov sogn, 1910. Minder fra Branderup sogn og Roost, 1911.

Troels Fink: Udskiftningen i Sønderjylland indtil 1770. 1941.

E. Lautrup: Chronik und Monographie der Stadt Hadersleben. 1844.

P. Rhode: Samlinger til Haderslev-Amts Beskrivelse. 1775.

Johannes v. Schrøder: Hertugdømmet Slesvigs Topographi. 1854.

Knud Aagaard: Beskrivelse over Trrning Lehn. 1815.

\section{NOTER}

1. I et foredrag på Koldinghus i 1934 behandlede dr. Lis Jacobsen et arbejde af magister C. A. Christensen om de to voldsteder i Arrild sogn. Foredraget blev trykt i Fortid og Nutid X samme år. I Festskrift til Johan Hvidtfeldt 1978 har C. A. Christensen igen behandlet emnet: Arnsholm og Valdemar Sappi.

2. Ifølge delingsakten for Roost Nørreby 1775 androg Fogedgården 821 holstenske tønder a ca. 2/3 hektar eller cirka 540 hektar. Boniteten taget i betragtning har dette været et helt usædvanligt stort flademål for en gård på egnen.

Aagaard beretter, at der skulle kunne avles 7a 800 læs hø på Fogedgården, hvilket efter to læs per kreatur per vinter skulle muliggøre vinterfodring af 350 a 400 kreaturer. Musvang kan dog være medregnet $i$ tallet for hølæs.

3. Jørgen Fausbøl: Minder fra Branderup sogn og Roost.

4. Rømet slægtens forhold kan ret nøje følges i dokumenter indeholdt i Løgumbogen.

5. Dr. G. Friis: Herredsfoged Nis Henriksen på Hajstrupgaard og hans Slægt. Sønderjydske Aarbøger. 1891.

6. Haderslev amtsarkiv.

7. Jørgen Fausbøl: Minder fra Branderup sogn og Roost.

8. I E. Lautrup: Chronik und Monographie der Stadt Hadersleben 1844, skildres på side 13537 tankerne om en deling af Haderslev amt $i$ et øster- og vesteramt. Det sidste ville formentligt have fåt Gram til amtsby.

9. I Sønderjyske Årbøger 1978 og 1980 gives der i artiklerne om Riesslægten i Stenderup og Forholdet mellem J. N. H. Skrumsager og Laurids H. Kaltoft skildringer af de meget selvbevidste bondeslægter, der udsprang af udskiftningstiden.

10. Oplysningerne om Christian Outzen hidrører dels fra en mundtlig tradition, dels fra direkte og indirekte omtale hos f.eks. Achelis, Nic. C. Nielsen, Fausbøl m.fl.

11. Søren Abildgaard. 1718-91. Arkivtegner og kunstmaler. Se Sønderjyske Årbøger 1906, side 103.

12. Jørgen Fausbøl: Minder fra Branderup Sogn og Roost. 
13. P. Rhode: Samlinger til Haderslev-Amts Beskrivelse. 1775, og Knud Aagaard: Beskrivelse over Tørning Lehn. 1815, giver meget udførlige skildringer af Haderslev Vesteramt.

Modsatningen mellem gsteramt og vesteramt kom f.eks. til udtryk ved amtsrådsvalget $i$ 1858 og spillede en stor rolle det sidste tiår af $H$. A. Krügers politiske virke.

14. Troels Fink: Udskiftningen i Sønderjylland indtil 1770. Side 127-129.

15. Rigsarkivet. Rentekammeret. Den slesvig-holstenske Landcommision 1768-1823. Korrespondancesager vedr. Haderslev Amt.

Udskrift af striden mellem ridefoged Peter Bramsløw og Dines Lauridsen, Herrestedgaard.

16. Oplysningerne er hentet i Jørgen Fausbøl: Minder fra Branderup Sogn og Roost, Nic. C. Nielsen og en ret righoldig mundtlig tradition, som der har måttet sorteres meget $i$ på grund af usikkerheden og ofte modstridende oplysninger.

17. Rigsarkivar Johan Hvidtfeldts optegnelser om husfogeder: Christian Outzen berømmes af Reventlow i Dagbogen 1796, fordi han havde indlagt sig en stor fortjeneste af udskiftningen i vesteramtet. (Statsminister, grev Christian Ditlev Reventlow (1748-1827)) Landsarkivet, Ábenrå.

18. Nic. C. Nielsen og mundtlig tradition.

\section{SLAGTSTAVLE}

Holden (?) Pedersen på Rømet, Toftlund sogn. omkr. 1400.

Peder Holdensen på Rømet, senere Branderup. Tinghører. Herredsfoged. form. født og død $\mathrm{i}$ 1400-tallet.

Tersten Pedersen på den senere Fogedgård i Roost, Sandemand, form. født i 1400-tallet, død i 1500-tallet.

Owe Terstensen på Roost Fogedgård, form. født i 1400-tallet og død i 1500-tallet.

Hans Outzen den Fldre i Roost, herredsfoged, født 1518, død 1589.

Hans Outzen den Yngre i Roost, herredsfoged, født 1556, død 1609.

Hans Hansen el. Outzen i Roost, herredsfoged, født $15 \ldots$, død omkr. 1657.

Hans Outzen i Brøns, senere Roost, ridefoged, født 1616, død 1689.

formentligt i slægt på fædrene og mødrene side med slægten i Roost. Testamentarisk arving.

Detlef Outzen i Roost, ridefoged, født omkr. 1650, død 1721.

Hans Outzen i Roost, husfoged, født 1687, død 1755.

Christian Outzen i Roost, husfoged, født 1732, død 1809.

Christian Outzen i Roost, født 1776, død 1828.

Hans Outzen i Roost, født 1823, død 1834. 